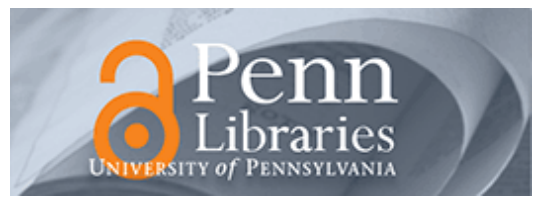

University of Pennsylvania

ScholarlyCommons

Management Papers

Wharton Faculty Research

2000

\title{
Coping With Trade-Offs: Psychological Constraints and Political Implications
}

Philip E. Tetlock

University of Pennsylvania

Arthur Lupia

University of California - San Diego

Mathew D. McCubbins

University of California - San Diego

Samuel L. Popkin

University of California - San Diego

Follow this and additional works at: https://repository.upenn.edu/mgmt_papers

Part of the Management Sciences and Quantitative Methods Commons

\section{Recommended Citation (OVERRIDE)}

Tetlock, P.E. (2000). Coping With Trade-Offs: Psychological Constraints and Political Implications. In A. Lupia, M.D. McCubbins \& S.L. Popkin (Eds.), Elements of Reason: Cognition, Choice, and the Bounds of Rationality (pp. 239-263). New York: Cambridge University Press. [doi: 10.1017/CBO9780511805813.011]

This paper is posted at ScholarlyCommons. https://repository.upenn.edu/mgmt_papers/261

For more information, please contact repository@pobox.upenn.edu. 


\title{
Coping With Trade-Offs: Psychological Constraints and Political Implications
}

\begin{abstract}
A thoughtful reader of the psychological literature on judgment and choice might easily walk away with the impression that people are flat-out incapable of reasoning their way through value trade-offs (Kahneman, Slovic, and Tversky 1982). Trade-offs are just too cognitively complex, emotionally stressful, and socially awkward for people to manage them effectively, to avoid entanglement in Tverskian paradoxes, such as intransitivities within choice tasks and preference reversals across choice tasks. But what looks impossible from certain psychological points of view looks utterly unproblematic from a microeconomic perspective. Of course, people can engage in trade-off reasoning. They do it all the time every time they stroll down the aisle of the supermarket or cast a vote or opt in or out of a marriage (Becker 1981). We expect competent, self-supporting citizens of free market societies to know that they can't always get what they want and to make appropriate adjustments. Trade-off reasoning should be so pervasive and so well rehearsed as to be virtually automatic for the vast majority of the noninstitutionalized population.

We could just leave it there in a post-positivist spirit of live-and-let-live pluralism. The disciplinary divergence provides just another illustration of how competing theoretical discourses construct reality in their own image. This "resolution" is, however, less than helpful to political scientists who borrow from cognitive psychology or microeconomics in crafting theories of political reasoning. The theoretical choice reduces to a matter of taste, in effect, an unconditional surrender to solipsism.

Disciplines

Management Sciences and Quantitative Methods
\end{abstract}




\section{1}

\section{Coping with Trade-Offs: Psychological Constraints and Political Implications PHILIP E. TETLOCK}

A thoughtful reader of the psychological literature on judgment and choice might easily walk away with the impression that people are flat-out incapable of reasoning their way through value trade-offs (Kahneman, Slovic, and Tversky 1982). Trade-offs are just too cognitively complex, emotionally stressful, and socially awkward for people to manage them effectively, to avoid entanglement in Tverskian paradoxes, such as intransitivities within choice tasks and preference reversals across choice tasks. But what looks impossible from certain psychological points of view looks utterly unproblematic from a microeconomic perspective. Of course, people can engage in trade-off reasoning. They do it all the time - every time they stroll down the aisle of the supermarket or cast a vote or opt in or out of a marriage (Becker 1981). We expect competent, self-supporting citizens of free market societies to know that they can't always get what they want and to make appropriate adjustments. Trade-off reasoning should be so pervasive and so well rehearsed as to be virtually automatic for the vast majority of the noninstitutionalized population.

We could just leave it there in a post-positivist spirit of live-and-let-live pluralism. The disciplinary divergence provides just another illustration of how competing theoretical discourses construct reality in their own image. This "resolution" is, however, less than helpful to political scientists who borrow from cognitive psychology or microeconomics in crafting theories of political reasoning. The theoretical choice reduces to a matter of taste, in effect, an unconditional surrender to solipsism.

I appreciate the editors' helpful comments on an earlier version of this essay, as well as the editorial and research assistance of Heather Kinney. The research reported in this chapter was supported by a grant from the National Science Foundation (BNS 732396) and assisted by three institutions: The Center for Advanced Study in the Behavioral Sciences, The Institute of Personality and Social Research of the University of California, Berkeley, and The Mershon Center of Ohio State University. 


\section{Tetlock}

At the risk, therefore, of appearing to be an epistemological primitive (a pre-post-positivist), I'll pose the Stone Age question "Who is right?" And, if we can not identify a clear winner, what exactly does it mean to assert that the "truth" lies somewhere between the rationalist and cognitivist positions? What boundary conditions can we identify? When does trade-off reasoning approximate the microeconomic ideal? And when do cognitive, emotional, and cultural constraints make themselves felt? Finally, what are the political implications? Are politicians who acknowledge trade-offs candidly at a serious public-relations disadvantage (as some psychological formulations would suggest)? Can we determine when acknowledging trade-offs can be politically lethal and when it might even be beneficial?

The first section of the chapter lays out the grounds for supposing the worst about the human capacity for coping with trade-offs. The case for pessimism draws on the work of behavioral decision theorists on choice heuristics and loss aversion (Kahneman, Slovic, and Tversky 1982; Kahneman and Tversky 1979); of cognitive consistency and psychodynamic theorists on "bolstering" (Festinger 1964; Janis and Mann 1977); and of anthropologists and social psychologists on "taboo trade-offs" (Fiske and Tetlock 1997; Tetlock, Peterson, and Lerner 1996). Taken together, these arguments suggest that people are reluctant decision makers who do their damnedest to minimize cognitive effort, emotional dissonance, and moral angst by denying that important values conflict. If we assume a pluralistic polity that regularly thrusts important values into sharp conflict (Berlin 1969, 1990), this portrait of the decision maker warns us to expect chronic mismanagement of trade-offs. People, certainly the mass public but probably also elites, will be slow to recognize that core values clash; they will rely on mental shortcuts that eliminate direct comparisons between clashing values; they will engage in the dissonance-reduction strategy of bolstering to reduce the stress of those value conflicts they are forced to acknowledge; and they will resort to decision-evasion tactics, such as buck-passing, procrastination, and obfuscation, to escape responsibility for making choices that inevitably leave some constituency feeling it has gotten the short end of the trade-
off stick.

The second section of the chapter qualifies this grim assessment of our capacity to cope with trade-offs. People are best thought of not as cognitive misers but rather as cognitive managers who deploy mental resources strategically as a function of the perceived importance and tractability of the problem. The value pluralism model of political reasoning is in this cognitive-managerial spirit - it specifies when people are likely to invest effort in overtly compensatory trade-off reasoning, as opposed to relying on simple, easy-to-execute heuristics. The model makes predictions con- 


\section{Coping with Trade-Offs}

cerning the main effects and interactive effects of political ideology, issue domain, institutional role, and electoral accountability on the complexity of trade-off reasoning. I survey the evidence bearing on these predictions - evidence that includes laboratory experiments on undergraduates, content analyses of both confidential interviews and public statements of elites, and representative-sample surveys of mass publics.

Finally, this chapter presents two exploratory lines of empirical work - one of which suggests that the value pluralism model may exaggerate the flexibility of trade-off reasoning (at least when such reasoning touches on taboo topics), and the other of which suggests that the value pluralism model is correct in crediting people with a metacognitive capacity to shift strategically from simple to complex to simple modes of thinking. Work on taboo trade-offs harkens us back to a pessimistic assessment of human rationality - a view of people as not just cognitive misers but as cognitive primitives who recoil from normatively suspect trade-offs in fear and horror. A key research question becomes: How literally should we take the designation taboo? Are taboo trade-offs "taboo" in the primal Polynesian senses of the term: (a) rooted in unreasoned aversion; (b) extraordinarily resistant to change; and (c) capable of contaminating anyone or anything associated with violations of the taboo? One set of studies investigated whether taboos are pure affect or are rooted in cause-effect beliefs about utilitarian consequences. They did so by assessing whether we could deactivate the moral outrage triggered by taboo trade-offs and present counterarguments designed to deflect common objections that people (who are not too consumed by outrage) offer to such trade-offs. A second set of studies examined the issue of contamination by assessing whether we could transform previously popular politicians into objects of scorn by revealing that their decision process violated the taboo proscription on affixing dollar values to human life. Both sets of studies suggest that taboo is an apt characterization of how half or more of college-educated samples in latetwentieth-century America deal with trade-offs that require attaching monetary values to objects, actions, rights, and responsibilities that our secular society deems sacred.

The other line of work contains more upbeat implications for defenders of mass rationality: It examines popular reactions to political rhetoric that either denies trade-offs (by claiming to possess a dominant option that is superior on all dimensions of comparison) or affirms trade-offs (by depicting choice as a complex balancing act in which different values must be given different weights in different situations). When do people see the embracing of trade-offs by politicians as evidence of moral weakness (lack of principles) and of mental confusion (trapped in the throes of Hamlet-like paralysis)? And when do they see the same style of rea- 


\section{Tetlock}

soning as evidence of a mature temperament that recognizes the contradictory demands of life? And how do people react to politicians who deny trade-offs? When do they find such political figures inspiring, energizing, and charismatic, or when do they suspect demagoguery? Although trade-off reasoning is often a net political liability, there are noteworthy exceptions. Much depends on the political temper of the times: If people have been primed by recent experiences to place a negative "value spin" on trade-off denial (the shrill demagogue) and a positive spin on trade-off acceptance (the thoughtful statesman), politicians who acknowledge trade-offs can even prevail in the competition for public favor.

So, where will this leave us? The empirical battle over rationality is but three or four decades old. The opening volley - the cognitive critique of homo economicus - scored palpable hits. But the severely bounded rationality of homo psychologicus - the cognitive miser who is prisoner of his or her simplification strategies - has proven too constraining and has already been superseded by a wave of cognitive-manager models that depict decision makers who decide how to decide and who can occasionally even approximate the ideal type of economic rationality. There are reasons for suspecting that this synthetic position - the cognitive manager - strikes a compelling compromise between the economic and psychological world views. But it is hardly likely to be the last word in this dialectical process. Cognitive managers work within complex constraints, including computational capacity, emotional arousal, and cultural norms. There is plenty of room for reasonable disagreement over how tightly constraining these constraints are in specific choice tasks. This chapter traces the yin/yang progression of this debate within my own research program.

\section{OBSTACLES TO TRADE-OFF REASONING}

Psychological theorists have identified at least four mutually reinforcing reasons for supposing that people are incapable of doing what microeconomic theory postulates people do routinely.

The first obstacle to trade-off reasoning is arguably the most fundamental: the incommensurability problem created by the absence of a common metric for translating competing values into each other. By definition, trade-offs require interdimensional comparisons - balancing proverbial apples and oranges - that people do not have the cognitive equipment to perform in reliable ways. Most of us do not have carefully calibrated subjective scales to generate judgments of the form: What loss of liberty would I accept to achieve this increment in public safety? How many young American lives is it worth sacrificing to stop genocide in 


\section{Coping with Trade-Offs}

eastern Europe or central Africa? Lacking the mental means for making the necessary interdimensional computations, people are hard-pressed to produce reliable (less still, utility-maximizing) answers to trade-off questions. Within choice tasks, we often observe breakdowns in the transitivity of preferences as people choose $A$ over $B, B$ over $C$, and $C$ over $A$. Across choice tasks, we often observe that the method of preference elicitation - for example, choice versus matching - determines which side of the issue people endorse. Intransitivities and preference reversals should simply never happen from the standpoint of rational-choice theory (Thaler 1991; Tversky and Thaler 1990). But these anomalies from a rational-choice point of view are readily explained by cognitive theories of choice that postulate widespread reliance on easy-to-execute heuristics. For instance, Tversky's (1972) elimination-by-aspects rule eliminates the cognitive strain of "compensatory" trade-off reasoning by allowing people to screen options "lexicographically," one value at a time, typically starting with the most important or salient value and eliminating all options that fail to pass some threshold, and then screening the remaining options on secondary values until only one remains. But there is no free lunch. The price of minimizing cognitive strain is susceptibility to error (in this case, intransitivities in preference). Ironically, the mental escape from trade-offs itself involves a trade-off - an effortaccuracy trade-off.

A second obstacle to trade-off reasoning is emotional. As Leon Festinger (1957) pointed out 40 years ago, most people find it dissonant to acknowledge to themselves that they have sacrificed one value for another. The more important the value, the greater the potential for anticipatory regret, in which people ponder what would have happened in the counterfactual world in which they chose the "other path." To avoid the cognitive dissonance of acknowledging that one is an incompetent or immoral decision maker, or to avoid sinking into depressive rumination about better possible worlds that could have been, people often "spread the alternatives." They exaggerate the importance of the chosen value and derogate the rejected value.

A third obstacle is fear of criticism. Critics can always accuse us of having chosen the wrong path, an especially tempting accusation given what prospect theory tells us about the psychophysical tendency for losses on the value we have sacrificed to loom larger than gains on the value we have chosen (Kahneman and Tversky 1979). Politicians quite rightly see early career changes in their future when they publicly endorse trade-offs that impose losses on key constituencies. The gratitude of the "winners" is rarely as intense or long-lived as the resentment of the losers.

The fourth obstacle is cultural. From a microeconomic perspective, it should be possible to reduce all values to a single utility metric. But cross- 


\section{Tetlock}

cultural analysis reveals that although people deem many trade-offs legitimate, they categorically reject others as contemptible and unworthy of any consideration. What accounts for the sharpness of this resistance? Tetlock et al. (1996) have argued that the resistance is not reducible to run-of-the-mill "incommensurability" - the cognitive difficulty of comparing proverbial apples and oranges. Such comparisons may be difficult, but we do them all the time when we balance our household budgets. Moreover, there is nothing embarrassing or shameful about admitting that we make trade-offs when we make decisions about the wine, meat, or leisure time we consume (unless in doing so, we reveal that we've violated some religious law or moral precept to which we supposedly adhere).

Rather, opposition to reducing diverse values to a single metric is rooted in "constitutive incommensurability." The guiding idea is that our commitments to other people forbid certain comparisons. To transgress these normative boundaries, to attach a monetary value to one's friendships or children or loyalty to a nation-state, is to disqualify oneself from certain social roles, to demonstrate that one just "doesn't get it" - one does not understand what it means to be a true friend or parent or citizen. We run into constitutive incommensurability whenever the treating of values as commensurable subverts one or both of the values in the trade-off calculus. To compare is to destroy. Even to think about certain trade-offs (less still, to make them) is to corrupt and degrade one's standing as a moral being in the larger community. In the words of the moral philosopher Joseph Raz (1986: 21): "It is impoverishing to compare the value of a marriage with an increase in salary. It diminishes one's potentiality as a human being to put a value on one's friendship in terms of improved living conditions." Durkheim (1973) expressed the same sentiment in sociological language when he observed that in both "primitive religious" and "advanced secular" societies, people ascribe a transcendental quality to fundamental values of their social order. Even sophisticated citizens of industrialized democracies tenaciously resist treating these sacred values as objects of market or political calculation. Their attitude is less one of utilitarian calculation than that of believers to their diety, a stance of absolute faith that imposes a mysterious barrier around social morality. Violations of sacred or ultimate values are not just cognitively perplexing; they are morally destabilizing. They shake the foundations of our social being, provoking both moral outrage and demands for punishment. And, as Daniel Bell (1980) argued, we should be none too sure that the inexorable advance of technical rationality will sweep such quasi-religious thinking away in the near future. Nineteenthcentury predictions of the "end of religion" in the twentieth century have proven, at best, embarrassingly premature. We may be observing here 


\section{Coping with Trade-Offs}

a deeply human resistance to the homogenization of experience in the technically precise formulas of cost-benefit analysis. People resent the institutional pressures to conform to the "iron-cage" imperatives of functional rationality and economic efficiency. They want - and sometimes insist upon - more out of life.

When one adds up all of the obstacles to trade-off reasoning, one certainly does not have a logically tight case that explicit trade-off reasoning is impossible, but one does have a strong case that it is likely to be rather rare and painfully difficult. One should expect that people will often mismanage trade-offs and that, although elites may be more attuned to value conflicts, educational achievement and social standing will confer little protection against the powerful psychological forces arrayed against candid, self-conscious, and overtly compensatory weighing of conflicting values (Sniderman, Fletcher, Russell, and Tetlock 1996). One should also expect widespread reliance on lexicographic shortcuts, such as elimination by aspects (Tversky 1972), and cybernetic shortcuts (Steinbruner 1974), such as sequential adaptation in which people discover that they have had enough of any given value only after they have had more than enough. These shortcuts "solve" the incommensurability problem by eliminating the need for direct comparisons of conflicting values. People can make trade-offs without being at all conscious of having done so. When the trade-off is called to public attention, we should expect widespread recourse to the trilogy of decision-evasion tactics (Tetlock and Boettger 1994) - buck-passing (transfer responsibility to others), procrastination (delay the day of reckoning), and obfuscation (render opaque where one stands and, ideally, who wins and who loses as a result). And when the trade-off is public knowledge, and so too is one's responsibility for making the final call, we should expect widespread resort to the dual dissonance-reduction strategies of denial and bolstering, playing down the strengths of the to-be-slighted value and playing up the strengths of the to-be-rejected value, thereby producing the classic "spreading-of-the-alternatives" effect.

How serious a threat do these trade-off avoidance strategies pose to political rationality? Much hinges on subtle issues of governance beyond the province of this chapter. But insofar as one believes, pace Berlin (1969), that trade-offs are a defining feature of any pluralistic polity in which competing groups can never get everything they want and claim to deserve, often as a matter of "right," there are ample grounds for concern. Once an issue has been successfully framed (in the Gamson, not the Kahneman, sense) as implicating a right, it becomes a taboo tradeoff that is exempted from the logrolling give-and-take of normal politics and ceases to be an openly negotiable item. And insofar as one believes that trade-off avoidance carries a steep price tag by inhibiting 


\section{Tetlock}

candid discussion of opportunity costs and looming threats, those grounds for concern are further reinforced. The more adroit interest groups become in framing their claims on collective resources as entitlements and rights, the more reluctant rational vote-maximizing politicians will be to make trade-offs that openly challenge the demosclerotic stranglehold those groups gradually acquire over national policy (cf. Olson 1982; Rauch 1995).

\section{THE VALUE PLURALISM MODEL}

Psychological arguments that stress the difficulty of trade-off reasoning inevitably collide with the arguments advanced by both evolutionary and economic theorists that trade-off reasoning is an indispensable and therefore universal skill. Coping with scarcity - of time, physical energy, emotional energy, and material resources - has been a fundamental feature of human existence for millions of years (cf. Cosmides and Tooby 1992). Coping with scarcity is also a defining feature of minimal competence for citizens in a free-market society in which all self-supporting adults are expected to set spending priorities within limited budgets (cf. Becker 1981). An apparent paradox thus arises: How do people cope as effectively with scarcity as they do if they are as inept as psychologists say at trade-off reasoning?

The value pluralism model - presented in detail in Tetlock et al. (1996) - strikes an uneasy compromise between the functionalist imperatives of survival in a world of scarcity and the psychological constraints on tradeoff reasoning revealed by the laboratory literature. This model asserts that although some people and ideological factions are more open to the possibility that core values clash than are others (a political personality postulate of the model), virtually everybody can be motivated to engage in trade-off reasoning when the optimal conditions hold, including that: (a) scarcity compels people to acknowledge that values conflict (transparency); (b) the values in conflict are both important and approximately equally important (equal activation/salience of competing values); (c) people believe that it is culturally acceptable to consider the trade-offs in question; (d) people see no socially acceptable way of avoiding taking a stand by invoking one of the trilogy of decision-evasion tactics - buckpassing, procrastination, and obfuscation; and (e) people believe that they are accountable to an audience that magnifies motives for selfcritical policy analysis and vigilance.

When all conditions are satisfied, we should expect a relatively rare pattern of cognitive processing to become quite common: namely, explicitly compensatory trade-off reasoning in which people acknowledge the legitimacy of conflicting values and propose integration rules for gener- 


\section{Coping with Trade-Offs}

ating compromises that give some weight to each conflicting value, with the weighting often varying with the context.

A host of hypotheses follow from the general logic of the value pluralism model. This section summarizes the key predictions and empirical results over the last 15 years:

(a) The model assumes that underlying all political belief systems are ultimate or terminal values (Lane 1973; Rokeach 1973) that specify the end-state goals of public policy. These values - which may take such diverse forms as economic efficiency, social equality, individual freedom, crime control, national security, and racial purity - function as the backstops of belief systems. When we press people to justify their policy preferences, all inquiry ultimately terminates in values that people find it ridiculous to justify any further. Antiabortion partisans consider "because life is sacred" a self-explanatory justification for their position just, as pro-choice partisans consider "women's liberty" to be a selfjustifying justification for their position.

Political ideologies do vary dramatically, however, in the degree to which they acknowledge conflicts among terminal values. Some belief systems are self-consciously pluralistic, accepting the pervasiveness of value conflict and the necessity of trade-offs; others are self-consciously monistic, depicting core values as perfectly harmonious, all pointing in one policy direction (Berlin 1969). From a value pluralism perspective, advocates of pluralistic (usually centrist) ideologies should be more practiced in complex trade-off reasoning than advocates of monistic (usually extremist) ideologies. Here we can report a rather reliable cross-national effect from content and structural analysis of intra-elite political debate: The point of maximum "integrative complexity" in elite political debate often peaks at the center or slightly to the left of center in legislative bodies, such as the U.S. Senate (Tetlock, Hannum and Micheletti 1984), the British House of Commons (Tetlock 1984), the Italian Chamber of Deputies (diRenzo 1967; Putnam 1971), and the Israeli Knesset (MaOz and Shayer 1987).

(b) The value pluralism model warns us, however, not to expect certain ideological groups to be always more prone to complex trade-off reasoning than other groups. Rather, the general expectation is for ideology-by-issue interactions in which the point of maximum complexity of trade-off reasoning shifts from one topical domain to another across ideological groups as a function of whether important and approximately equally important values have been brought into conflict by the framing of the issue. For instance, Tetlock (1986) found that liberals were most likely to reason in integratively complex trade-off terms when the issue frame brought economic efficiency into conflict with social equality (Okun's, 1975, "big trade-off"), whereas conserva- 


\section{Tetlock}

tives engaged in the most overtly compensatory trade-off reasoning when the issue frame brought national defense and fiscal prudence into conflict.

(c) The value pluralism model also warns us not to treat explicit trade-off reasoning as inherently cognitively or morally superior to categorical rejection of trade-offs. It is not difficult to identify historical contexts within which contemporary sympathies overwhelmingly favor those factions that vociferously denied trade-offs: Churchillian opponents of British appeasement of Nazi Germany in the 1930s who denounced Chamberlain's effort to strike a subtle balance between deterrence and reassurance (Tetlock and Tyler 1996); and abolitionists in the slavery debates of antebellum America who denounced free-soil Republicans who sought integratively complex compromises that would avert war and preserve the Union, but indefinitely preserve slavery in southern states (Tetlock, Armor, and Peterson 1994). It is also not difficult to identify historical contexts within which contemporary observers deplore not just one but both of the values that complex trade-off reasoners attempted to balance against each other. Pragmatic Nazis were quick in World War II to recognize the gruesome trade-off between their goals of mobilizing military resources to win the war and devoting resources to the extermination of Jews. There is nothing intrinsically morally meritorious about trade-off reasoning.

(d) The value pluralism model stresses the importance of political accountability as a moderator of how people deal with value conflict (Tetlock 1992). Complex trade-off reasoning should be more common in the rhetoric of governing parties that have responsibility for coping with scarcity than it should be among opposition parties (whose primary role is to incite resentment among those who feel they are getting the short end of the trade-off stick from the governing party). In line with this reasoning, Tetlock, Hannum, and Micheletti (1984) found that when control of both Congress and the presidency shifted from liberals to conservatives, there was a decline in trade-off reasoning in liberal rhetoric and a corresponding increase in conservative rhetoric. Indeed, Gruenfeld (1995) has shown that this "minority-majority" effect even holds up among decision makers who are not subject to electoral accountability, namely, justices of the U.S. Supreme Court. Majority opinions - which often require delicate coalition building and have the force of law contain more explicit trade-off reasoning than do minority opinions, which offer authors the moral luxury of waxing indignant about the shortcomings of the majority opinion.

(e) Given the limited capacity of the mass public to process complex political messages, the value pluralism model predicts that imminent accountability to the electorate should reduce complex trade-off reason- 


\section{Coping with Trade-Offs}

ing, at least in public statements. In the competitive heat of campaigns, political parties should find it advantageous to simplify their messages and downplay trade-offs, thereby minimizing opportunities for critics to highlight trade-offs that impose losses on identifiable, perhaps electorally decisive, constituencies. This prediction holds up well for most presidents of the twentieth century (Tetlock 1981a). But there may well be historical and political-cultural boundary conditions on this hypothesis: How people respond to rhetoric of varying complexity hinges on the evaluative schemata that are most readily accessible for information processing.

Shifting from past to ongoing work, we turn now to two exploratory lines of research. One examines the possibility that there is a large class of trade-offs to which the value pluralism model does not apply - taboo trade-offs to which people are incapable of responding strategically and can only give a gut or visceral response. The other line of work is more in the spirit of the value pluralism model: It examines the possibility that people intuitively appreciate both the strengths and drawbacks of complex trade-off reasoning but must be primed by salient situational cues to apply this knowledge to the evaluation of political candidates and arguments.

\section{TABOO TRADE-OFFS: LIMITS ON THE MENTAL \\ FLEXIBILITY OF COGNITIVE MANAGERS}

Research on trade-off reasoning has been so completely dominated by utilitarian models of choice that little attention has been given to the possibility that people simply refuse to contemplate - at least consciously certain trade-offs. Research on taboo trade-offs (in utilitarian terms, values that people stubbornly insist must be assigned infinite value) must therefore grapple with foundational issues. Accordingly, we begin with the definitional problems of what exactly constitutes a taboo trade-off and of which operational indicators might be used to ascertain whether we have stumbled upon a taboo. Conceptual and operational preliminaries to the side, we pose three additional questions: (1) How broad a consensus is there within American political culture on what is a taboo trade-off? (2) Are taboos absolute and unreasoned prohibitions, or is it possible to talk people out of their aversions by presenting arguments that address concerns they may have about the consequences of violating the taboo? (3) Do violations of taboos have the power to contaminate perpetrators and policy proposals associated with them? The second and third issues raise the question of whether taboo trade-offs are taboo in the original anthropological sense of the term. If so, it should be extraordinarily difficult to persuade people to abandon their aversions, and it 


\section{Tetlock}

should be extraordinarily easy for violations of taboos to taint, perhaps ruin, political careers.

\section{Moral Outrage as a Defining Property of Taboo Trade-Offs}

Our working definition of a taboo trade-off was any comparison that people deemed illegitimate because the comparison subverted or destroyed a culturally cherished value. Drawing on several lines of inquiry, including attribution theory, cognitive appraisal theories of emotion, and Durkeim's (1973) classic characterization of how people react to violations of the collective conscience, Tetlock et al. (1996) developed a moral outrage index to gauge reactions to "illegitimate" trade-offs. The index consisted of three components that corresponded to the traditional tripartite definition of attitudes (McGuire 1968). The cognitive component consisted of dispositional attributions to anyone who would seriously consider making a taboo trade-off or to anyone who would seriously consider permitting such conduct. Observers often rate advocates of such policy proposals as auctioning babies for adoption or buying and selling human organs for medical transplants as immoral, depraved, and even insane. The affective component consisted of the emotional reactions to transgressors: anger, contempt, and even disgust. Finally, the behavioral-intentional component consisted of support for punishing transgressors and of a desire to ostracize people who are unwilling to punish and perhaps even willing to tolerate such conduct. When respondents judged a series of transactions requiring trade-offs that intuitively varied from the uncontroversial to the contested to the taboo in mainstream political culture, the cognitive, affective, and behavioral components of the outrage index intercorrelate sufficiently to define a scale that passes the usual psychometric standards for internal consistency, with alphas between 0.7 and 0.85 , depending on the exact items included in the scale.

\section{Ideological Subcultures}

With an index of moral outrage for gauging reactions to taboo status in hand, it is reasonable to ask how much consensus exists on what constitutes a taboo trade-off. Tetlock et al. (1996) found substantial consensus within mainstream political culture, with only a few pockets of sharp disagreement, but that the consensus fades quickly toward ideological fringes of society. They asked college student activists with a wide ideological range to report their reactions to three a priori types of tradeoff transactions: relatively uncontroversial secular-secular (buying and selling goods and services that American citizens are normally permit- 


\section{Coping with Trade-Offs}

ted, even encouraged, to exchange); theoretically taboo secular-sacred (buying and selling goods and services that the American legal system attempts to insulate from the "universal solvent of money"); and sacredsacred (trade-offs that pit against each other two values both of which are normally insulated from the universal solvent of money).

Several noteworthy results emerged. Most politically consequential, there was substantial agreement between conservative Republicans and liberal Democrats that a wide range of "blocked exchanges" (Andre 1992; Walzer 1983) should indeed remain blocked. In the broadly defined center of the political spectrum - ranging, say, from Ted Kennedy to Jesse Helms - most people concur that moral outrage is the appropriate response to proposals to permit the auctioning of unwanted babies for adoption, competitive markets for transplant organs, and the buying and selling of basic rights and obligations of citizenship, such as draft deferments, eligibility for citizenship, and votes. But the consensus is imperfect. Flash points of disagreement emerge even within the mainstream. Liberals view the buying and selling of conventional medical services and, to some degree, legal services as suspect categories - people seem to be buying health, life, and justice - whereas conservatives are not bothered by such transactions. And these disagreements become extremely pronounced as we move to the libertarian right and the Marxist left. Many transactions that mainstream political culture condemns libertarians accept and even enthusiastically endorse (such as market mechanisms for the placement of unwanted babies and for ensuring an adequate supply of human organs for medical transplants). Only a few conventionally taboo trade-offs elicit moral outrage from libertarians (e.g., paying someone to go to jail in one's place); by and large, they reserve their outrage for the censorious busybodies who invent "moral externalities" that prevent consenting adults from entering into mutually beneficial pacts, thereby thwarting society's movement toward the Pareto frontier. By contrast, it is difficult to find transactions that do not elicit at least some outrage from Marxists. Our Marxist respondents were prototypical "censorious busybodies." Even routine market transactions - hiring someone to clean one's house and, indeed, the buying and selling of one's house - provoke a measure of moral condemnation from Marxists, who view labor and commodity markets as inherently exploitative.

But our analysis thus far has been both ethnographically and psychologically thin. We have essentially rediscovered normative prohibitions on value trade-offs that thoughtful citizens already knew existed. And we have rediscovered ideological cleavages that will come as no surprise to political philosophers. Indeed, if the results had come out otherwise, our first reaction would have been to question whether the 


\section{Tetlock}

self-avowed Marxists and libertarians from undergraduate clubs truly understood the creeds that they ostensibly espoused. It is possible, however, to pose deeper questions about the psychocultural status of "taboo" trade-offs - questions with greater potential to yield surprising answers.

\section{Taboo Trade-Offs: Unreasoned Aversion or Thoughtful Ideological Stands?}

Imagine that someone proposes to permit a regulated market for buying and selling human organs - hearts, lungs, kidneys, livers, corneas - for medical transplants. Or imagine that someone proposes to allow all "qualified parents" (who pass the regular standards for adopting children) to bid for the right to adopt particular children in need of loving and supportive families. If you are like the overwhelming majority of our sample of 155 undergraduates, your first response is likely to be moral outrage - a composite of emotional and cognitive reactions and punitiveness. These policy proposals elicit such a powerful negative response because they breach taboos; they allow people to affix dollar values to something - human bodies and babies - that well-socialized beings are supposed to regard as sacred. But are taboo trade-offs "taboos" in the Malinowskian meaning of the term, absolute prohibitions, like that on incest, that require no further explanation? Or is there a cognitive component to these aversions? Is it possible to elicit reasons that people object to markets for babies and body organs? And by addressing those reasons in revised policy proposals, is it possible to overcome the resistance?

Approximately $60 \%$ of those who object to "marketizing" babies and body organs saw no need for a reason - even when held accountable and pressed for one - beyond the blanket condemnation that "the policy is degrading, dehumanizing, and unacceptable." We take this assertion to be simply a reassertion of the taboo - an "ugh" reaction that people find odd to be asked to justify. It is as though we had reached the backstop of these belief systems - the de gustibus line of defense where people find further queries to be absurd. But what about the $40 \%$ of respondents who offer rather specific reasons for considering the proposal unacceptable? Informal content analysis of these reasons revealed that many objections had an egalitarian character. One common concern about medical transplants is the fear that the poor will be driven into deals of desperation. They will need money so badly that they will feel compelled to submit to dangerous surgical interventions - donating part of one's liver or a kidney - that the well-off would never seriously consider. A widely held fear about baby auctions was that only healthy and attrac- 


\section{Coping with Trade-Offs}

tive babies would draw bidders. A related concern is that the price of organs and babies will skyrocket and the market will cater only to the well-off. Another class of objection is more pragmatic or instrumental. Some people are not convinced that all other options have been investigated for increasing the supply of body organs for desperately needed transplants or the supply of parents for babies in need of families. These respondents suspect that "more civilized" solutions to the shortage of organs and parents can be found.

Our research on the "cognitive substrate" of taboo trade-offs assessed how much people change their minds about markets for body organs when we revised the policy proposal to address substantive objections that people raised. One series of questions included the following:

Would you still object to markets for body organs: (a) if you lived in a society that had generous social welfare policies and never allowed the income for a family of four to fall below $\$ 32,000$ per year (explaining the concept of inflation-adjusted 1996 dollars)?; (b) if society provided the less well-off with generous "organ-purchase vouchers" that increased in value as recipient income decreased (the poorer the recipient, the larger the voucher)?; (c) if it could be shown that all other methods of encouraging organ donation had failed to produce enough organs and that the only way to save large numbers of lives was to implement a market for body organs?

Another series of questions probed reactions to permitting all qualified parents to bid for adoption rights. In one scenario, subjects were assured that if only attractive and healthy babies attracted high bids, then the money raised through the auction would go to create incentives to encourage other parents to adopt less attractive and less healthy babies, as well as to improve the current conditions of institutionalized life for these children. In another scenario, respondents were assured that poor people would not be prevented from adopting children because the program would provide generous vouchers to all poor people who want to adopt children, thereby permitting them to compete with the affluent would-be adopters (again, explaining the concept of vouchers). In a third scenario, subjects were assured that all less-radical possible solutions to the problem of nonadopted children had been explored and proven inadequate.

How successful were we in eroding the taboo through this series of counterfactual thought experiments? Whereas nearly $90 \%$ of respondents initially objected to each proposal, opposition fell to approximately $60 \%$ in the hypothetical worlds with protection for the poor and unattractive and a guarantee that all other options had been thoroughly explored. For nearly half of the population, the term taboo is apparently too strong. They are willing to consider - in a quasi-utilitarian manner 


\section{Tetlock}

- conditions under which the benefits of the proposal might conceivably outweigh the costs. For the other half of respondents, though, the term taboo still seems apt. They are prepared to ban exchanges that both donors and recipients believe would leave them better off and that, arguably, would leave many third parties better off as well. In their eyes, taboo trade-offs remain an affront to the collective conscience, a kind of moral externality. As one female respondent protested, "What kind of people are we becoming?" Consequentialist arguments - whether they invoked egalitarian or efficiency concerns - missed the point: This woman's sense of personhood required categorically rejecting the taboo trade-offs. In March and Olson's (1989) terminology, the logic of obligatory, not anticipatory, action governed her choices. She knew with existential certainty who she was, and she knew that she did not fit into a social world that countenanced such transactions. Her decision process is perhaps better modeled as pattern matching than as utility maximizing.

\section{Taboo Trade-Offs as Sources of Political Contamination}

Imagine that someone confronts you with what initially looks like a standard OMB-style cost-benefit analysis that makes the case for reducing funding for an inefficient program designed to achieve a worthy goal, such as building hospitals in underserved rural areas, cleaning up toxic waste dumps to the point of zero risk, or eliminating all carcinogens from new food additives. If you are like most respondents - about $75 \%$ of them - your first response will be annoyance with government waste and gratitude for those who are trying to stem the hemorrhaging of taxpayer dollars into ineffective programs. Let's say, however, that the cost-benefit analysis includes an explicit dollar valuation of human life. Support for the would-be reformers should now plummet, and they should be pilloried as callous, arrogant, and inhumane.

Operationally, the taboo-contamination experiment takes the following form. In one condition, the taboo trade-off is covert. It is masked by a "deontic" justification that vaguely declares that "morally, it is the right thing to do." The specific scenario was inspired by the Superfund Act:

A government program cleans up toxic waste sites to the point where they pose zero risk to public health. Last year, the program saved an estimated 200 lives at a cost of $\$ 200$ million. The Danner Commission - whose mandate is to improve the efficiency of government - investigated the program and recommended a set of reforms that were implemented. As a result, this year the program could save an estimated 200 lives - just as many as before - but at a 


\section{Coping with Trade-Offs}

cost of only $\$ 100$ million, a saving of $\$ 100$ million. If the government kept funding the program at last year's budget level of $\$ 200$ million, the program could save an estimated 400 lives.

Now the Danner Commission recommends redirecting the saving of $\$ 100$ million to other uses, including reducing the deficit, increased funding for programs to stimulate economic growth, and lowering taxes. Based on its analysis of these options, the commission concludes that "morally this is the right thing to do." What do you think? Should the government keep funding the program at $\$ 200$ million or should it redirect the $\$ 100$ million saved to other priorities?

After ensuring that all subjects fully comprehended the policy choice confronting them (via a knowledge test), subjects voted on this proposal, rated their agreement on scales ranging from "strongly favor keeping funding at $\$ 200$ million" to "strongly favor redirecting the $\$ 100$ million to other priorities," and rated the Danner Commission on a host of identity dimensions (moral, competent, and so on).

By contrast, in another experimental condition, subjects learned that

based on its analysis of the options, the Danner Commission has concluded that the cost of saving the additional 200 lives is about $\$ 500,000$ per life - a cost that it still considers too high and one that cannot be justified, given other needs and priorities. The Commission therefore recommends redirecting the saving of $\$ 100$ million to other uses, including reducing the deficit, increased funding for programs to stimulate economic growth, and lowering taxes.

Support for the Danner Commission recommendation hovers at $72 \%$ when the trade-off is masked by a deontic rationale, but falls to approximately $35 \%$ when the trade-off explicitly violates the normative injunction against dollar valuations of human life.

Additional experimental conditions address alternative interpretations. One argument is that people object not to attaching a dollar value to human life but rather to the particular cost estimate that the Danner Commission endorsed. There is nothing inherently wrong about pricing human life, but one should get the price right. To explore this possibility, subjects reacted to a commission that engaged in costbenefit reasoning and concluded that funding should remain at $\$ 200$ million because $\$ 500,000$ per human life is a cost worth bearing. In still other conditions, $\$ 500,000$ is a bargain; the commission would have been willing to pay either $\$ 1$ million or $\$ 10$ million. Although people judge the commission more favorably when it places a higher dollar value on human life, they still judge it less favorably, and substantially so, than when the commission offers a deontic rationale either for keeping 


\section{Tetlock}

funding at the $\$ 200$ million level or for redirecting spending to other priorities. ${ }^{1}$

Another possibility is that people object to utilitarian reasoning in general and not just to the violation of this specific taboo trade-off. To test this possibility, subjects reacted to a Danner Commission that either redirected funding or kept funding constant and did so "after weighing all the relevant costs and benefits." Interestingly, vague utilitarian reasoning was every bit as effective in providing political cover as vague deontic reasoning. Tragic choices are best cloaked (Calabresi and Bobbit 1978), and either Kantian or utilitarian cloaks will do the job. People objected to the explicit spelling out of the trade-off. Doing so tarnished the image of a previously well-regarded reformist commission, rendering suspect its entire policy agenda.

These experiments show that previously popular politicians and acceptable policies can be transformed into objects of scorn by revealing that the politicians performed taboo mental calculations in reaching their conclusions. The damage to one's political identity can be so severe that even possessing an otherwise winning utilitarian argument is not sufficient to prevail in the court of public opinion. The "contamination" findings have important implications. Ambitious proposals to reform budget-busting entitlement programs - Medicare, Social Security - or more modest efforts to cap programmatic budgets can become politically poisonous as soon as defenders successfully frame the issue (in the Gamsonian sense) so that the budget cutters appear guilty of a taboo trade-off. The breaches of taboos might take diverse forms: "breaking faith with the elderly" (what price a promise to our grandparents?), "placing a dollar value on the health of the poor or elderly" (what price a life?), "betraying veterans who risked their lives for our country" (what price a sacred trust?), and "short changing the education and care of the young" (what price a child's dreams?). Big-ticket spending items are not, moreover, the only issues that implicate taboos. Defenders of the Superfund effort to reduce the risk posed by toxic waste dumps to zero, or of the Delaney Clause to ban new food additives that are at all carcinogenic, can always accuse opponents of acting as fronts for business groups who put profits over the lives of children who might eat contaminated dirt or artificially sweetened cereal. In a similar vein, advocates of campaign finance reform can stigmatize opponents as "holding up American democracy for sale"; proponents of state-financed health insurance and legal care can warn of devaluing the lives of the poor and decreasing their access to justice; oppo-

1 The dollar valuation of $\$ 10$ million per life is fantastically high; it would quickly exhaust American economic resources as of 1996. The entire U.S. federal budget could save only approximately 170,000 lives. 


\section{Coping with Trade-Offs}

nents of capital punishment can argue that it is only a matter of time before an innocent man or woman is executed in a state-sanctioned murder and that, surely, any moral person would pay any price to avoid complicity in such an atrocity.

At this juncture, rational-choice theorists might argue that savvy politicians do not really believe taboo issue framings; they use such rhetoric to cudgel their opponents into submission. Psychological theorists might respond in three ways. First, the presumed efficacy of taboo rhetoric hinges at least on a receptive public, thus conceding the argument at the mass level. Second, the line between rhetoric and reality, public posturing and private thought, is often a fine one. Even accomplished politicians sometimes come to believe what they say via the processes of dissonance reduction and self-perception. Third, there is always the danger of rhetorical blowback (Snyder 1991). Once one announces that Social Security or Jerusalem or Kashmir is sacred and therefore nonnegotiable, one may convince others who, in turn, will hold one accountable for any deviation from that declaratory principle. Politicians thus become prisoners of their own rhetoric.

A more compelling rational-choice rejoinder is the game-theoretic observation that both sides are continually searching for taboo trump cards to play in the rhetorical competition for public support. Thus, we should expect a public dialogue of the deaf, as each side wraps itself in the mantle of a sacred value. But there is hope here for trade-off reasoning inasmuch as our data reveal people to be much more tolerant of sacred-sacred trade-offs than they are of secular-sacred trade-offs. Putting contending values on an equal, moral playing field can be a contribution in itself. As the late Aaron Wildavsky was fond of arguing, environmental programs that claim to save lives need to be weighed not against a dollar metric (opportunity costs of foregone growth) but against another life metric by invoking the causal argument that wealthier is healthier. But this example also illustrates another point: It is rhetorically easier to "sacralize" some issue stands than others. The two-step Wildavskian argument for economic growth requires more cognitive sophistication of the audience than the one-step environmentalist argument: Stop poisoning us!

\section{PRIMING POLITICAL SCRIPTS: DEMAGOGIC OR PRINCIPLED? THOUGHTFUL OR CONFUSED?}

The second line of work swings the pendulum partly back toward the rational end of the theoretical continuum on public opinion: It explores whether people have a deeper understanding of trade-off reasoning than the psychological literature has given them credit for possessing. The key 


\section{Tetlock}

idea is simple: An integral part of folk knowledge in our political culture is that it is possible to attach either positive or negative value spins to either complex trade-off acceptance or simple trade-off denial. Most people can readily imagine circumstances under which they would approve of complex trade-off reasoning - indeed, see it as a prerequisite for any mature, balanced, and thoughtful leadership. Let's label these mental scenarios the "thoughtful statesman script." But most people can also readily imagine circumstances under which they might view tradeoff reasoning to be morally suspect - as prima facie evidence of a lack of principles, indecisiveness, and a tendency to straddle the fence, vacillate, and obfuscate. There are some things we should not even think of compromising. Let's call this set of mental scenarios the "opportunistic vacillator script." Conversely, looking at simple trade-off denial, many people can imagine circumstances under which they would deplore this style of thinking as evidence that the decision maker is rigid, selfrighteous, and perhaps flat-out incapable of understanding other points of view - what we will call the "demagogue script." But many people can also imagine circumstances under which they might applaud tradeoff deniers as courageous, resolute, and decisive souls who resist the temptation to try to be everything to everybody - what we will call the "principled leader script."

If we postulate that most people have internalized schemata or scripts that portray simple and complex trade-off reasoning in both flattering and unflattering lights, then drawing on the extensive literature on priming of knowledge structures (Higgins 1996), we should be able to increase the likelihood of positive or negative responses to trade-off reasoning by affecting the mental accessibility of these knowledge structures. ${ }^{2}$ Consider the following experiment that adapts standard priming methods for manipulating cognitive availability to the study of perceptions of political leaders. In the first phase of the study (ostensibly concerned with memory), subjects receive biographical information about a politician and expect to be tested for the accuracy of their recall. In one condition, this biographical portrait primes people to think of negative stereotypes of complex trade-off thinkers (the opportunistic vacillator) and of positive stereotypes of simple thinkers (the principled leader); in a second condition, people are primed to think of the opposite stereo-

Note that this psychological approach does not give people as much credit for a self-conscious capacity to shift from simple to complex modes of thinking as does the cognitive-manager position at the heart of the value pluralism model. Rather, it portrays the shift in evaluative standards (anti to pro complexity) as an automatic reaction to a priming cue, a function of the spreading activation laws of associative memory that determine the ease of retrieving particular cognitions and, hence, the likelihood of those cognitions influencing judgment. 


\section{Coping with Trade-Offs}

types in which complexity connotes thoughtfulness and balance (the thoughtful statesman) and simplicity connotes rigidity, intolerance, and self-righteousness (the demagogue); in a third (control) condition, people receive no prime whatsoever.

Here is part of the prime designed to activate the thoughtful statesman script:

Abercrombie is really different from most politicians. He does not shy away from complex problems that have no clear right answers. He tries to understand all points of view (not just those of his campaign donors), to weigh conflicting perspectives carefully in the balance, and to arrive at an integrative judgment only after all the relevant evidence has been thoroughly investigated. He understands that responsible policy must involve trade-offs and compromises among competing groups and constituencies that have legitimate interests at stake. And he is willing to change his mind later should new evidence arise. Even his worst critics have to admire his balanced and thoughtful approach to public policy.

The other prime was designed to activate the evaluative script for the principled leader:

Abercrombie is really different from most politicians. He does not hold up his finger to figure out which way the wind is blowing. He sizes up situations quickly and decisively and makes his positions unmistakably clear, with no attempt to confuse people about where he stands with talk about "on the one hand" and "on the other hand." He also does not suffer fools gladly. When he thinks someone is spouting nonsense, he lets them know it. And once he does take a stand, you can count on him to stay the course and to be loyal to his convictions. Even his worst critics have to admire his courageous and principled approach to public policy.

After recall tests to ensure that subjects had attended to the "primes," all subjects moved to a different room under the guidance of a different experimenter to participate in a supposedly unrelated study of attitudes toward controversial issues. Subjects then listened to excerpts from two political speeches: one on the balanced budget amendment and the second on school vouchers. The experimental design is rather complex. Each speech took one of six forms. The speaker either supported or rejected the policy proposal and engaged in either no trade-off reasoning or moderately or extremely complex trade-off reasoning in reaching this policy conclusion.

The "trade-off denial" anti-voucher speech warned of "the destruction of public education and the creation of deep and divisive inequities in access to quality education, inequities far worse than currently exist." In the pro-voucher condition, the trade-off-denying speaker urged "the introduction of badly needed competition in a public school system that 


\section{Tetlock}

only the relatively wealthy can now escape. Only by vigorously stimulating competition can we improve the quality of education for the entire population and ensure that schools are run for the benefit of the children, not public service employees' unions and overpaid administrators." The moderately complex trade-off acceptance speech conceded the legitimacy of the arguments invoked by the other side but then proceeded to take exactly the same side as before. The highly complex trade-off acceptance speech not only conceded some legitimacy to the other side's concerns but noted that which position you take depends on balancing competing risks, as well as on which factual claims you believe. The speaker conceded that there were good grounds for being suspicious of public monopolies but also good grounds for believing that education is a legitimate and central function of government (ensuring that all citizens have some common experiences in growing up). The speaker also conceded that there were good grounds for believing in markets (that they deliver goods and services more efficiently) but went on to acknowledge good grounds for expecting markets to amplify inequality. The speaker concluded by noting that where one comes out on this issue hinges partly on judgments of which consequences one considers more likely (issues of fact), and partly on which consequences one deems more important (issues of moral valuation). The speaker then came down on one side or the other (always as emphatically as in the simple speech so as to hold the perceived issue position of the speaker as constant as possible across conditions).

The trade-off denial speech in support of the balanced budget amendment declared that

our federal government has demonstrated, beyond a reasonable doubt, that it was incapable of living within its means. Our elected representatives will always give in to special interests that demand just one more tax loophole, one more subsidy, one more low-interest loan, one more pork-barrel project. ... Without the discipline of a binding, no-loophole constitutional amendment, the country will inexorably continue on a path of rising indebtedness - that, to our collective shame, we will bequeath to future generations.

The antiamendment trade-off-denial speech depicted the balanced budget amendment as yet

one more ploy by antigovernment forces to strangle popular spending programs that these politicians do not dare attack directly. The balanced budget amendment would prevent flexible government responses to economic recessions and national emergencies. The balanced budget amendment is also profoundly unfair and inefficient. It is unfair to ask people in the present to pay out of pocket for all long-term improvements that they make to the education, transportation, and health-care systems that will be available to people of the future. And it is inef- 


\section{Coping with Trade-Offs}

ficient because it will stifle initiative in areas where government can make an important long-term difference, such as promoting economic growth and scientific and technological innovation.

In the moderately complex trade-off statement, the speaker concedes the legitimacy of both perspectives and then comes down emphatically on one side. In the high complexity trade-off statement, the speaker not only acknowledges the legitimacy of the competing perspectives but specifies that the positions which one takes hinge, in part, on how skeptical one is about the American political system and, in part, on how effectively one believes government can direct resources to programs that will lay the basis for long-term prosperity. Does one believe, for example, that the government can intervene - in hard times - to reinvigorate the economy by creating jobs and guaranteeing everyone a minimal standard of living? The speaker then announces that based on his answers to these questions, he has come out solidly in opposition or support of the balanced budget amendment (in an effort once again to hold the perceived issue position constant across experimental conditions).

Three results merit special mention. First, priming or making accessible widely held stereotypes of trade-off reasoning had a big effect. Subjects primed by the thoughtful statesman script became increasingly positive toward complex trade-off arguments (rating the speaker as balanced, thoughtful, and even wise), and increasingly negative toward simple arguments that denied or minimized trade-offs (rating the speaker as simplistic, rigid, and intolerant). Second, subjects primed by the script for the principled leader moved in exactly the opposite directions. They responded more positively to the speaker who denied tradeoffs (rating the speaker as strong and decisive), and less positively to the speaker who depicted the choice process as balancing conflicting legitimate concerns (rating the speaker as confused, uncertain, and indecisive). This pattern of trait attributions fits neatly into a $2 \times 2$ Peabody (1967) plot that allows us to sort out the positive and negative connotative meanings that people attach to the denotative dimension of simplicity complexity reasoning (Tetlock, Berry, and Peterson 1993). Third, control subjects who were not primed resembled subjects who had been exposed to the anticomplexity prime - a result that held especially strongly for subjects who scored highly on a self-report measure of dogmatism and intolerance of ambiguity. This pattern suggests that the principled leader script may be more spontaneously accessible than is the thoughtful statesman script. As a result, speakers who simply deny trade-offs may often have an advantage over their more complex counterparts.

A final study explored reactions to simple or complex trade-off reasoning in arguably the most polarized of all political debates in the last 


\section{Tetlock}

few decades, namely, abortion. Using a brief questionnaire to classify undergraduates in a large subject pool as either unequivocally pro-life, unequivocally pro-choice, or deeply ambivalent, this study assessed the reactions of subjects with strong "priors" to a political figure who took a pro or anti abortion stand and who did so in one of three ways: by denying that any trade-off was involved whatsoever and declaring that there was an unambiguous correct answer; by acknowledging that tradeoffs existed and that there was uncertainty about the right answer (there was a risk of compromising one or another sacred value, e.g., life versus liberty); or by acknowledging the highly complex nature of the tradeoffs involved by noting not only the legitimacy of conflicting sentiments but by specifying philosophical perspectives that should incline us to judge one or the other risk to be more or less acceptable.

Three findings again merit mention. First, the more complex the tradeoff rationale that a politician offers for a pro-life or pro-choice stand, the less trusted and respected that politician is by those on the politician's side. We call this the "traitor" effect. The politician is, in the eyes of supporters, guilty of treasonous thoughts by failing to reject the other side's perspective categorically. Second, offering a complex trade-off rationale for a policy position on abortion does not gain the politician much approval from the other side, even though the politician acknowledges the legitimacy of their perspective. If anything, there is a trend in the opposite direction. Political partisans find it galling that someone can recognize the legitimacy of their point of view but not agree with it. Third, practitioners of complex trade-off rhetoric do at least enjoy an advantage among people who are "deeply ambivalent" on the issue of abortion. This group does indeed respond more positively to complex trade-off rhetoric.

\section{CONCLUDING COMMENTS}

It is useful to be explicit about the implications of these initial results for both our image of human nature and for democratic political theory. With respect to human nature, people appear neither to be hopelessly muddled incompetents when it comes to trade-offs (as a caricature of the cognitive literature might suggest) nor to be adroit practitioners of multivariate calculus who can perform conditional optimization problems in their sleep. That said, however, there is a lot of room in between. The emerging portrait of the trade-off reasoner is mixed. Many people believe that their core values do not conflict and they need to be prodded, sometimes poked pretty hard, into acknowledging that these values do conflict. But once primed to believe that trade-offs are a pervasive feature of political life, they become quite skeptical of rhetorical claims to have 


\section{Coping with Trade-Offs}

identified a dominant solution, often dismissing them as implausible, shrill, manipulative, and even demagogic.

With respect to democratic political theory, if we take sensitivity to trade-offs to be a necessary condition for thoughtful participation in a pluralistic polity, the current results offer grounds for both optimism and pessimism. Those inclined to see the glass a quarter full can point to ways of activating our latent potential to recognize value trade-offs and generate integrative solutions. They can also point to ways of stimulating skepticism toward politicians who bear trade-off-free policy packages and receptiveness toward politicians who tell us "painful truths" about conflicts between core values. But those inclined to see the glass threequarters empty can point to the low frequency of trade-off reasoning in general; to the high frequency with which people deny even obvious trade-offs; to the great difficulty most people have in generating integrative solutions to those trade-offs they do recognize; to the far more enthusiastic response most people have to simple rhetoric that denies trade-offs than to complex trade-off rhetoric that acknowledges tradeoffs; and to the ease with which taboo trade-offs can contaminate otherwise reasonable policy proposals, forcing politicians to retreat into simplistic cant or obfuscatory ruses. In short, the current findings hardly demonstrate that deliberative democracy is psychologically impossible, but they do highlight the opportunities that our judgmental weaknesses create for skillful political manipulators. 


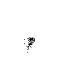




\section{References}

Abelson, R. 1959. "Modes of Resolution of Belief Dilemmas." Journal of Conflict Resolution 3: 343-352.

Abelson, R. 1963. "Computer Simulation of 'Hot' Cognition." In S. S. Tomkins and S. Messick, eds., Computer Simulation of Personality. New York: Wiley, 277-298.

Abelson, R. 1973. "The Structure of Belief Systems." In R. Schank and K. Colby, eds., Computer Models of Thought and Language. New York: Freeman, 287-339.

Abelson, R. 1987. "Conviction." American Psychologist 43: 267-275.

Abelson, R., E. Aronson, W. McGuire, T. Newcomb, T. Rosenberg, and P. Tannenbaum. 1968. Theories of Cognitive Consistency: A Source Book. Chicago: Rand McNally.

Abelson, R., and D. Prentice. 1989. "Beliefs as Possessions: A Functional Perspective." In A. Pratkanis, S. Brecker, and A. Greenwald, eds., Attitude Structure and Function. Hillsdale, NJ: Lawrence Erlbaum, $361-382$.

Adorno, T., E. Frenkel-Brunswick, D. Levinson, and N. Sanford. 1950. The Authoritarian Personality. New York: Harper and Row.

Alchian, A. A. 1950. "Uncertainty, Evolution and Economic Theory." Journal of Political Economy 58: 211-221.

Aldrich, J. H. 1995. Why Parties? Chicago: University of Chicago Press.

Allwood, C. M., and H. Montgomery. 1987. "Response Selection Strategies and Realism of Confidence Judgments." Organizational Behavior and Human Decision Processes 39: 365-383.

Altemeyer, R. 1981. Right-Wing Authoritarianism. Winnipeg, Manitoba: University of Manitoba Press.

Althaus, S. L. 1996. Who Speaks for the People? Political Knowledge, Representation, and the Use of Opinion Surveys in Democratic Politics. Ph.D. dissertation, Northwestern University.

Anderson, J. 1983. The Architecture of Cognition. Cambridge, MA: Harvard University Press.

Anderson, N. 1991. Contributions to Information Integration Theory. Hillsdale, NJ: Lawrence Erlbaum. 


\section{References}

Anderson, N., and S. Hubert. 1963. "Effects of Concomitant Recall on Order Effects in Personality Impression." Journal of Verbal Learning and Verbal Behavior 2: 379-391.

Andre, J. 1992. "Blocked Exchanges: A Taxonomy." Ethics 103: 29-47.

Ansolabehere, S., and S. Iyengar. 1994. "Riding the Wave and Exercising Ownership Over Issues." Public Opinion Quarterly 58: 335-357.

Ansolabehere, S., and S. Iyengar. 1995. Going Negative: How Attack Ads Shrink and Polarize the Electorate. New York: Free Press.

Aristotle. 1954. Rbetoric. New York: Modern Library.

Aronson, E. 1992. "The Return of the Repressed: Dissonance Theory Makes a Comeback." Psychological Inquiry 3: 303-311.

Arrow, K. J. 1973. "Formal Theories of Social Welfare." In P. Wiener, ed., Dictionary of the History of Ideas, 4: 276-284. New York: Scribner.

Arthur, W. B. 1988. "Self-reinforcing Mechanisms in Economics." In P. W. Anderson, D. Pines, and K. Arrow, eds., The Economy as an Evolving Complex System. Boston: Addison-Wesley, 33-48.

Arthur, W. B. 1990. "A Learning Algorithm that Mimics Human Learning." Santa Fe Institute Economics Research Program, Working Paper 90-026, Santa Fe, NM.

Arthur, W. B., 1992. "On Learning and Adaptation in the Economy." Institute for Economic Research Discussion Paper \#854, Queen's University, Kingston, Ontario, Canada.

Aumann, R. J. 1981. "Survey of Repeated Games." In R. J. Aumann et al., eds., Essays in Game Theory and Mathematical Economics in Honor of Oskar Morgenstern. Zurich: Bibliographisches Institut, 11-42.

Axelrod, R. 1984. The Evolution of Cooperation. New York: Basic Books.

Bacon, F. 1621 and 1994. Noutm Organum. Translated and edited by P. Urbach and J. Gibson. Chicago: Open Court.

Bargh, J. 1994. "The Four Horseman of Automaticity: Awareness, Intention, Efficiency, and Control in Social Cognition." In R. Wyer and T. Srull, eds., Handbook of Social Cognition: Basic Processes, Vol. I. Hillsdale, NJ: Lawrence Erlbaum Associates.

Bargh, J. 1997. "The Automaticity of Everyday Life." In R. Wyer, ed., Advances in Social Cognition. Vol. 10. Hillsdale, NJ: Lawrence Erlbaum Associates.

Bargh, J., S. Chaiken, R. Govender, and F. Pratto. 1992. "The Generality of the Automatic Attitude Activation Effect." Journal of Personality and Social Psychology 62: 893-912.

Barkow, J. H., L. Cosmides, and J. Tooby. 1992. The Adapted Mind: Evolutionary Psychology and the Generation of Culture. New York: Oxford University Press.

Baron, D. P. 1989. "A Noncooperative Theory of Legislative Coalitions." American Journal of Political Science 33: 1048-1084.

Baron, J. 1994. Thinking and Deciding. Cambridge: Cambridge University Press.

Baron, J., R. Gowda, and H. Kunreuther. 1993. "Attitudes Toward Managing Hazardous Waste: What Should Be Cleaned Up and Who Should Pay for It?" Risk Analysis 13: 183-192.

\section{References}

Barsalou, L. 1992. Cognitive Psychology: An Overview for Cognitive Scientists. Hillsdale, NJ: Lawrence Erlbaum Associates.

Bartels, L. M. 1995. "The American Public's Defense Spending Preferences in the Post-Cold War Era." Public Opinion Quarterly 58: 479-508.

Poters: Information Fffects in Presidential Elections." American Journal of Political Science 40: 194-230.

. 1932. Remembering: A Study in Experimental and Social Psychology. New York: Cambridge University Press.

Bates, R. H 1989. Beyond the Miracle of the Market: The Political Economy of Agrarian Development in Kenya. Cambridge: Cambridge University Press.

Batson, C. D. C. L. Turk, L. L. Shaw, and T. R. Klein. 1995. "Information Function of Empathetic Emotion: Learning That We Value the Other's Welfare." Journal of Personality and Social Psychology 68: 300-313.

aumer, D. L., and H. J. Gold. 1995. "Party Images and the American Electorate." American Politics Quarterly 23: 33-61.

Baumol, W. J., and W. E. Oates. 1979. Economics, Environmental Policy and the Quality of Life. Englewood Cliff, NJ: Prentice Hall.

. Tranel, and A. R. Damasio. 1997. "Deciding Advantageously Before Knowing the Advantageous Strategy." Science 275: $1293-1294$.

Becker, C. L. 1932. The Heavenly City of the Eighteenth Century Philosophers. New Haven: Yale University Press.

Becker, G. 1981. A Treatise on the Family. Cambridge, MA: Harvard University Press.

Press. "The Return of the Sacred? The Argument on the Future of Religion." In D. Bell, ed., The Winding Passage. New York: Basic Books. gion." In D. Bell, ed., The Winding Passage. New Yew York: Longman.

Bennett, W. L. 1988. News: The Politics of Illusion. New York. Longman. Bennett, W. L. 1992. The Governing York: St. Martin's Press.

American Elections. New York: St. Martin's Press.

Berelson, B. R., P. F. Lazarsfeld, and W. N. McPhee. 1954. Voting: A Study of Opinion Format. Chicago Press.

Berg, J., J. Dickhaut, and K. McCabe. 1995. "Trust, Reciprocity, and Social History" Games and Economic Behavior 10: 122-142.

Berlin, I. 1969. "Two Concepts of Liberty." In I. Berlin, Four Essays on Liberty. Oxford: Oxford University Press.

Bettelheim, B. 1989. The Uses of Enchantment: The Meaning and Importance of Fairy Tales. New York: Vintage.

Bikhchandani, S D. Hirshleifer, and I. Welch. 1992. "Theory of Fads, Fashion, Custom, and Cultural Change as Informational Cascades." Journal of Political Economy 100: 992-1026.

Binmore, K. 1987 and 1988. "Modeling Rational Players: Parts I and II." Economics and Philosopby $3: 179-214 ; 4: 9-55$.

Bnmore, K. 1993. Game Theory of the Social Contract 1: Playing Fair. Ann Arbor: University of Michigan Press. 


\section{References}

Bless, H., G. L. Clore, N. Schwarz, V. Golisano, C. Rabe, and M. Wolk. 1996 "Mood and the Use of Scripts: Does a Happy Mood Really Lead to Mindlessness?" Journal of Personality and Social Psychology 71: 665-679.

Bodenhausen, G. 1993. "Emotions, Arousal, and Stereotypic Judgments: A Heuristic Model of Affect and Stereotyping." In D. Mackie and D. Hamilton, eds, Affect, Cognition, and Stereotyping: Interactive Processes in Group Perception. San Diego: Academic Press, 13-37.

Bodenhausen, G. V., G. P. Kramer, and K. Süsser. 1994. "Happiness and Stereotypic Thinking in Social Judgments." Joumal of Personality and Social Psychology 66: 621-632.

Bogdan, R. J. 1997. Interpreting Minds: The Evolution of a Practice. Cambridge, MA: MIT Press.

Boniger, D. S., J. A. Krosnick, and M. K. Berent. 1995. "Origins of Attitude Importance: Self-Interest, Social Identification, and Value Relevance." Journal of Personality and Social Psychology 68: 61-80.

Boynton, G. R., and M. Lodge. 1994. "Voter's Images of Candidates." In A. Miller and B. Gronbeck, eds., Presidential Campaigns and American Self Images. Boulder, CO: Westview Press, 159-175.

Boynton, G. R., and M. Lodge 1996. "J.Q.PUBLIC: A Computational Model of Candidate Evaluation." Paper presented at the annual meeting of the American Political Science Association, San Francisco.

Brady, H. E., and P. Sniderman. 1985. "Attitude Attribution: A Group Basis for Political Reasoning." American Political Science Review 79: 1061-1078.

Brehm, J., and W. M. Rahn. 1997. "Individual-Level Evidence for the Causes and Consequences of Social Capital." American Journal of Political Science 41: $999-1023$

Brewer, P. R., and M. R. Steenbergen. 1997. "All For One or One Against All? The Impact of Interpersonal Trust on Public Opinion." Paper presented at the annual meeting of the Southern Political Science Association, Nov. 5-8, Norfolk, VA.

Breyer, S. 1993. Breaking the Vicious Circle: Toward Effective Risk Regulation. Cambridge, MA: Harvard University Press.

Brody, R., and B. Page. 1972. "The Assessment of Policy Voting." American Political Science Review 66: 450-458.

Bruner, J. 1986. Actual Minds, Possible Worlds. Cambridge, MA: Harvard University Press.

Bryant, A. 1996. "Advertising." New York Times, June 6, sec. D.

Buchanan, B. 1991. Electing a President: The Markle Commission's Report on Campaign '88. Austin: University of Texas Press.

Budge, I., and D. Fairlie. 1983. Explaining and Predicting Elections. London: Allen and Unwin.

Bueno de Mesquita, B., and D. Lalman. 1992. War and Reason: Domestic and International Imperatives. New Haven: Yale University Press.

Burns, P. 1985. "Experience and Decision Making: A Comparison of Students and Businessmen in a Simulated Progressive Auction." Research in Experimental Economics 3: 139-157.

\section{References}

Cacioppo, J. T., and R. E. Petty. 1979. "Effects of Message Repetition and Position on Cognitive Response, Recall, and Persuasion." Journal of Personality and Social Psychology 37: 97-109.

acioppo, J. T., and R. E. Petty. 1985. "Central and Peripheral Routes to Persuasion: The Role of Message Repetition." In A. Mitchell and L. Alwitt, eds, Psychological Processes and Advertising Effects. Hillsdale, NJ: Lawrence Erlbaum.

Cain, B. I. Ferejohn, and M. P. Fiorina. 1987. The Personal Vote: Constituency Service and Electoral Independence. Cambridge, MA: Harvard University Service

Cain, M. 1998. "An Experimental Investigation of Motives and Information in the Prisoners' Dilemma Game." Advances in Group Processes 15: 133160

Calabresi, G., and P. Bobbitt. 1978. Tragic Choices. New York: Norton.

Camerer, C. 1995 "Individual Decision Making." In J. H. Kagel and A. E. Roth eds., The Handbook of Experimental Economics. Princeton: Princeton University Press.

Camerer, C. F, and H. Kunreuther. 1989. "Decision Processes for Low Probability Events: Policy Implications." Journal of Policy Analysis and Management 8: 565-592.

Campagna, A. S. 1994. The Economy in the Reagan Years: The Economic Conequences of the Reagan Administration. Westport, CT: Greenwood Press.

Campbell, A., P. Converse, W. Miller, and D. Stokes. 1960. The American Voter. New York: John Wiley and Sons.

Campbell, D. T. 1987. "Evolutionary Epistemology." In D. T. Campbell, G. Raditzky, and W. W. Bartley III, eds., Evolutionary Epistemology, RatioRadity and the Sociology of Knowledge. La Salle, IL: Open Court, 47-90.

Carmines, E. G., and J. H. Kuklinski. 1990. "Incentives, Opportunities, and the Lofic Public Opinion in American Political Representation." In J. A. Logic of Public Opinion in Ami, Information and Democratic Processes. Urbana: University of Illinois Press.

The Managerial Revolution in American Business. Cambridge, MA: Harvard University Press.

American Business. Camil Rationality. Cambridge, MA: MIT Press.

Churchland, P. M. 1989. A Neurocomputational Perspective: The Nature of Mind and the Structure of Science. Cambridge, MA: MIT Press.

Churchland, P. M. 1995. The Engine of Reason, the Seat of the Soul: A Philosophical Journey into the Brain. Cambridge, MA: MIT Press.

Computational Brain. Cambridge, MA: MIT Press.

Clark 1989. Microcognition: Philosophy, Cognitive Science and Parallel Distributed Processing. Cambridge, MA: MIT Press.

Clark, A. 1993. Associative Engines: Connectionism, Concepts, and Representational Change. Cambridge, MA: MIT Press.

Clark, A. 1997. Being There: Putting Brain, Body, and World Together Again. Cambridge, MA: MIT Press. 


\section{References}

Clark, A., and A. Karmiloff-Smith. 1994. "The Cognizer's Innards: A Psychological and Philosophical Perspective on the Development of Thought." Mind and Language 8: 487-519.

Clore, G., and L. Isbell. 1999. "Emotion and Virtue and Vice," In James Kuklinski, ed., Citizens and Politics: Perspectives from Political Psychology. New York: Cambridge University Press.

Cobb, M. D., and J. H. Kuklinski. 1997. "Changing Minds: Political Arguments and Political Persuasion." American Journal of Political Science 41: 88-121.

Collier, D., and S. Levitsky. 1997. "Democracy with Adjectives: Conceptual Innovation in Comparative Research." World Politics 49: 430-451.

Collins, A., and E. Loftus. 1975. "A Spreading-Activation Theory of Semantic Processing." Psychological Review 82: 407-428.

Collins, A., and M. R. Quillian. 1968. "Retrieval Time from Semantic Memory." Journal of Verbal Leaming and Verbal Behavior 8: 240-247.

Conover, P. J. 1984. "The Influence of Group Identifications on Political Per ception and Evaluation." Journal of Politics 46: 760-785.

Converse, P. E. 1964. "The Nature of Belief Systems in Mass Publics." In D. E. Apter, ed., Ideology and Discontent. New York: Free Press.

Converse, P. E. 1970. "Attitudes and Nonattitudes: Continuation of a Dialogue." In D. Apter, ed., Ideology and Discontent. New York: Free Press, 206 261.

Converse, P. E. 1990. "Popular Representation and the Distribution of Information." In J. A. Ferejohn and J. H. Kuklinski, eds., Information and Demo cratic Processes. Urbana: University of Illinois Press.

Cosmides, L. 1989. "The Logic of Social Exchange: Has Natural Selection Shaped How Humans Reason? Studies with the Wason Selection Task." Cognition 31: 187-276.

Cosmides, L., and J. Tooby. 1992. "Cognitive Adaptations of Social Exchange." In J. H. Barkow, L. Cosmides, and J. Tooby, eds., The Adapted Mind: Evolutionary Psychology and the Generation of Culture. Oxford: Oxford University Press, 163-228.

Coulson, S. 1995. "Analogic and Metaphoric Mapping in Blended Spaces." Center for Research in Language Newsletter 9:2-12.

Coulson, S. 1996. "The Menendez Brothers Virus: Analogical Mapping in Blended Spaces." In A. Goldberg, ed., Conceptual Structure, Discourse, and Language. Stanford, CA: Center for the Study of Language and Information.

Coulson, S. 1997. Semantic Leaps: The Role of Frame-Shifting and Conceptual Blending in Meaning Construction. Ph.D. dissertation, University of California, San Diego.

Coursey, D. L., and E. A. Dyl. 1990. "Price Limits, Trading Suspensions, and the Adjustment of Prices to New Information." Unpublished manuscript, Business School, Washington University, St. Louis, MO.

Coursey, D. L., and C. F. Mason. 1987. "Investigations Concerning the Dynamics of Consumer Behavior in Uncertain Environments." Economic Inquiry
25: 549-504.

\section{References}

Cox, G. W. 1997. Making Votes Count: Strategic Coordination in the World's Electoral Systems. Cambridge: Cambridge University Press.

Cox, G. W., and M. D. McCubbinș. 1993. Legislative Leviathan: Party Government in the House. Berkeley and Los Angeles: University of California Press.

Crandall, R. W. 1997. "The Costly Pursuit of the Impossible." Brookings Review 15: $41-47$.

Crick, F. 1994. The Astonishing Hypothesis: The Scientific Search for the Soul. New York: Charles Scribner's Sons.

Critical Review. 1995. "Rational Choice Theory and Politics." New Haven, CT: Critical Review Foundation.

Damasio, A. R. 1994. Descartes' Error: Emotion, Reason, and the Human Brain. New York: G. P. Putnam's Sons.

Dawes, R. M. 1988. Rational Choice in an Uncertain World. San Diego: Harcourt Brace Jovanovich.

Delli Carpini, M. X., and S. Keeter. 1991. "Stability and Change in the U.S Public's Knowledge of Politics." Public Opinion Quarterly 55: 583-612.

Delli Carpini, M. X., and S. Keeter. 1996. What Americans Know About Politics and Why It Matters. New Haven: Yale University Press.

Delprato, D. J., and B. D. Midgley. 1992. "Some Fundamentals of B. F. Skinner's Behaviorism." American Psychologist 47: 1507-1520.

Denzau, A., and P. Grossman. 1993. "Punctuated Equilibria: A Model and Application of Evolutionary Economic Change." Unpublished manuscript, Economics Department, Washington University, St. Louis, MO.

Denzau, A. T., and D. C. North. 1994. "Shared Mental Models: Ideologies and Institutions." Kyklos 47: 3-31.

Derryberry, D, and D. M. Tucker. 1994. "Motivating the Focus of Attention." In P. M. Niedenthal and S. Kitayama, eds., The Heart's Eye. San Diego, CA: Academic Press, 167-196.

Devine, P. 1989. "Stereotypes and Prejudice: Their Automatic and Controlled Components." Journal of Personality and Social Psychology 56: 680690.

Dimock, M. A. 1997. "Political Knowledge and Voter Strategies for Candidate Assessment in Congressional Elections." Paper presented at the annual meeting of the Western Political Science Association, March 13-15, Tucson, AZ.

Dimock, M. A. 1998. "Knowledge, Trust, Community and Public Policy Attitudes." Paper presented at the annual meeting of the American Political Science Association, Sept. 3-6, Boston, MA.

Dimock, M. A., and S. L. Popkin. 1995. "Knowledge, Trust and International Attitudes." Paper presented at the annual meeting of the American Political Science Association, Chicago, IL.

Dimock, M. A., and S. L. Popkin. 1997. "Political Knowledge in Comparative Perspective." In S. Iyengar and R. Reeves, eds., Do the Media Govern: Politicians, Voters, and Reporters in America. Thousand Oaks, CA: Sage Publications. 
DiRenzo, G. J. 1967. Personality, Power, and Politics: A Social Psychological Analysis of the Italian Deputy and His Parliamentary System. Notre Dame, IN: University of Notre Dame Press.

Ditto, P. H., and D. F. Lopez. 1992. "Motivated Skepticism: Use of Differential Decision Criteria for Preferred and Nonpreferred Conclusions." Journal of Personality and Social Psychology 63: 568-584.

Downs, A. 1957. An Economic Theory of Democracy. New York: Harper and Row.

Durkheim, E. 1973. Moral Education. New York: Free Press.

Durkheim, E. 1976. The Elementary Forms of the Religious Life. $2 \mathrm{~d}$ ed. London: Allen and Unwin.

Eagly, A., and S. Chaiken. 1984. "Cognitive Theories of Persuasion." In L. Berkowitz, ed., Advances in Experimental Social Psychology, 17: 267-359. New York: Academic Press.

Eagly, A., and S. Chaiken. 1993. The Psychology of Attitudes. Fort Worth, TX: Harcourt Brace Jovanovich.

Easley, D., and J. Ledyard. 1992. "Theories of Price Formation and Exchange in Double Oral Auctions." In D. Friedman and J. Rust, eds., The Double Auction Market: Institutions, Theories and Evidence. Redwood City, CA: Addison-Wesley.

Eavey, C. L. 1986. "Committee Games and Fairness Norms." Paper presented at the annual meetings of the APSA in Washington, D.C., September.

Eavey, C. L., and G. J. Miller. 1984. "Fairness in Majority Rule Games with Core." American Journal of Political Science 28: 570-586.

Eckel, C. C., and P. Grossman. 1996. "The Relative Price of Faimess: Gender Differences in a Punishment Game." Journal of Economic Behavior and Organization 30: 143-158.

Ehrenberg, R. G., and R. S. Smith. 1997. Modern Labor Economics: Theory and Public Policy. 6th ed. Reading, MA: Addison-Wesley.

Eldredge, N., and S. J. Gould. 1972. "Punctuated Equilibria: An Alternative to Phyletic Gradualism." In T. J. M. Schopf, ed., Models in Paleobiology. San Francisco: Freeman, Cooper and Co., 82-115.

Elster, J. 1989. Nuts and Bolts for the Social Sciences. Cambridge: Cambridge University Press.

Elster, J. 1999. Alchemies of the Mind: Rationality and the Emotions. Cambridge: Cambridge University Press.

Enelow, J. M., and M. J. Hinich. 1984. The Spatial Theory of Voting. Cambridge: Cambridge University Press.

Fauconnier, G. 1994. Mental Spaces: Aspects of Meaning Construction in Natural Language. 2d ed. Cambridge: Cambridge University Press, 1994. [1st ed. Cambridge, MA: MIT, 1985]

Fauconnier, G. 1997. Mappings in Thought and Language. Cambridge: Cambridge University Press.

Fauconnier, G., and M. Turner. 1994. "Conceptual Projection and Middle Spaces." UCSD Cognitive Science Technical Report 9401. San Diego. [Available from cogsci.ucsd.edu and from www.wam.umd.edu/-mturn]
Fauconnier, G., and M. Turner. 1996. "Blending as a Central Process of Grammar." In A. Goldberg, ed., Conceptual Structure, Discourse, and Language. Stanford, CA: Center for the Study of Language and Information, 113-130. [Expanded web version: www.wam.umd.edu/ mturn/WWW] centralprocess.WWW/centralprocess.html]

Fauconnier, G, and M. Turner. 1998a. "Conceptual Integration Networks." Cognitive Science 22: 133-187.

Fauconnier, G., and M. Turner. 1998b. "Principles of Conceptual Integration." In J. P. Koenig, ed., Conceptual Structure, Discourse, and Language, II. Stanford, CA: Center for the Study of Language and Information.

Fazio, R. 1995. "Attitudes as Object-Evaluation Associations: Determinants, Consequences, and Correlates of Attitude Accessibility." In R. Petty and J. Krosnick, eds., Attitude Strength: Antecedents and Consequences. Hillsdale, NJ: Lawrence Erlbaum Associates, 247-282.

Fazio, R, D. Sanbonmatsu, M. Powell, and F. Kardes. 1986. "On the Automatic Activation of Attitudes." Journal of Personality and Social Psychology 50: 229-238.

Fazio, R., and C. Williams. 1986. "Attitude Accessibility as a Moderator of the Attitude-Perception and Attitude-Behavior Relations: An Investigation of the 1984 Presidential Election." Journal of Personality and Social Psychology 51: 505-514.

Feldman, J. 1959. An Analysis of Predictive Behavior in a Two-Choice Situation. Ph.D. dissertation, Carnegie Institute of Technology.

Feldman, S. 1988. "Structure and Consistency in Public Opinion: The Role of Core Beliefs and Values." American Joumal of Political Science 32: 416- 440 .

Feldman, S. 1995. "The Survey Response." In M. Lodge and K. McGraw, eds., Political Judgment: Structure and Process. Ann Arbor: University of Michigan.

Ferejohn, J. A. 1990. "Information and the Electoral Process." In J. A. Ferejohn and J. H. Kuklinski, eds., Information and Democratic Processes. Urbana: University of Illinois Press.

Ferejohn, J. A., and M. Fiorina. 1974. "The Paradox of Nonvoting: A Decision-Theoretic Analysis." American Political Science Review 68: $525-536$.

Ferejohn, J. A., and J. H. Kuklinski, eds. 1990. Information and Democratic Processes. Urbana: University of Illinois Press.

Festinger, L. 1957. A Theory of Cognitive Dissonance. Stanford, CA: Stanford University Press.

Festinger, L. 1964. Conflict, Decision, and Dissonance. Stanford, CA: Stanford University Press.

Fiorina, M. P. 1981. Retrospective Voting in American National Elections. New Haven: Yale University Press.

Fischhoff, B., P. Slovic, and S. Lichtenstein. 1977. "Knowing with Certainty: The Appropriateness of Extreme Confidence." Journal of Experimental Psychology: Human Perception and Performance 3: 552-564. 


\section{References}

Fishbein, M., and I. Ajzen. 1975. Belief, Attitude, Intention, and Behavior: An Introduction to Theory and Research. Reading, MA: Addison-Wesley.

Fishkin, J. S. 1997. The Voice of the People: Public Opinion and Democracy. New Haven: Yale University Press.

Fiske, A., and P. E. Tetlock. 1997. "Taboo Trade-offs: Reactions to Transactions that Transgress Spheres of Justice." Political Psychology 18: 255-297.

Fiske, S. 1981. "Social Cognition and Affect." In J. Harvey, ed., Cognition, Social Behavior, and the Environment. Hillsdale, NJ: Lawrence Erlbaum Associ ates, 227-264.

Fiske, S. T., and S. E. Taylor. 1991. Social Cognition, 2 d ed. New York: McGraw-Hill.

Flood, M. M. 1952. "Some Experimental Games." Rand Corporation Research Monograph, RM 789-1, June 20, Rand Corporation, Santa Monica, CA.

Flood, M. M. 1958. "Some Experimental Games." Management Science 5: 5-26.

Foucault, M. 1965. Madness and Civilization. Translated by Richard Howard. New York: Random House.

Freeman, M. 1997. "Grounded Spaces: Deictic -self Anaphors in the Poetry of Emily Dickinson." Language and Literature 6: 7-28.

Friedman, D., and J. Rust, eds. 1992. The Double Auction Market: Institutions, Theories and Evidence. Redwood City, CA: Addison-Wesley.

Friedman, M. 1953. Essays in Positive Economics. Chicago: University of Chicago Press.

Friedman, M. 1962. Capitalism and Freedom. Chicago: University of Chicago Press.

Frohlich, N. 1974. "Self Interest or Altruism, What Difference?" Journal of Conflict Resolution 18: 55-73.

Frohlich, N., and J. A. Oppenheimer. 1992. Choosing Justice: An Experimental Approach to Ethical Theory. Berkeley: California University Press.

Frohlich, N., [and J. A. Oppenheimer]. 1995. "The Incompatibility of Incentive Compatible Devices and Ethical Behavior: Some Experimental Results and Insights." Public Choice Studies 25: 24-51. [Incorrectly published without Oppenheimer's name.]

Frohlich, N., and J. A. Oppenheimer, 1996a. "Experiencing Impartiality to Invoke Fairness in the n-PD: Some Experimental Results." Public Choice 86: $117-135$.

Frohlich, N., and J. A. Oppenheimer. 1996b. "On Measuring Self Interest through Dictator Experiments: Some Problems." Presented at the Southern Economics Association Meetings, Washington Hilton Hotel, Washington, DC, Nov. 15.

Frohlich, N., and J. A. Oppenheimer. 1997. "A Role for Structured Observation in Ethics." Social Justice Research 10: 1-21.

Frohlich, N., and J. A. Oppenheimer, with P. Bond and I. Boschman. 1984. "Beyond Economic Man." Journal of Conflict Resolution 28: 3-24.

Frohlich, N., J. A. Oppenheimer, T. Hunt, and H. Wagner. 1975. "Individual Contributions for Collective Goods: Alternative Models." Joumal of Conflict Resolution 19: 310-329.

\section{References}

Fukuyama, F. 1995. Trust: The Social Virtues and the Creation of Prosperity. New York: Free Press.

Gambetta, D. 1988. "Can We Trust Trust?" In D. Gambetta, ed., Trust: The Making and Breaking of Cooperative Relations. Oxford: Basil Blackwell.

Geddes, B., and J. Zaller. 1989. "Sources of Popular Support for Authoritarian Regimes." American Journal of Political Science 33: 319-347.

Gilens, M. 1996. "Race Coding and White Opposition to Welfare." American Political Science Review 90: 593-604.

Gillette, C. P., and J. E. Krier. 1990. "Risk, Courts, and Agencies." University of Pennsylvania Law Review 138: 1027-1109.

Gode, D. K., and S. Sunder. 1992a. "Lower Bounds for Efficiency of Surplus Extraction in Double Auctions." In D. Friedman and J. Rust, eds., The Double Auction Market: Institutions, Theories and Evidence. Redwood City, CA: Addison-Wesley.

Gode, D. K., and S. Sunder. 1992b. "A Comparative Analysis of Efficiency of Economic Institutions with Zero Intelligence Traders." GSIA Working Paper 1992-23, Carnegie-Mellon University.

Gode, D. K., and S. Sunder. 1993. "Allocative Efficiency of Markets with Zero Intelligence (ZI) Traders: Market as a Partial Substitute for Individual Rationality" Joumal of Political Economy 101: 119-137.

Goldstein, D. 1997. "Political Advertising and Political Persuasion in the 1996 Presidential Campaign." Paper presented at the annual meeting of the American Political Science Association, September.

Graber, D. 1984. Processing the News: How People Tame the Information Flow. New York: Longman.

Grabowski, H., and J. Vernon. 1983. The Regulation of Pbarmacenticals. Washington, DC: American Enterprise Institute.

Green, D. P. 1988. "On the Dimensionality of Public Sentiment toward Partisan and Ideological Groups." American Journal of Political Science 32: $758-780$.

Green, D. P., and A. E. Gerken. 1989. "Self-Interest and Public Opinion toward Smoking Restrictions and Cigarette Taxes." Public Opinion Quarterly 53 $1-16$.

Griffin, D., and A. Tversky. 1992. "The Weighing of Evidence and the Determinants of Confidence." Cognitive Psychology 24: 411-435.

Grossman, P., and C. C. Eckel. 1996. "Anonymity and Altruism in Dictator Games." Games and Economic Behavior 16: 181-191.

Gruenfeld, D. H. 1995. "Status, Ideology, and Integrative Complexity on the U.S. Supreme Court: Rethinking the Politics of Political Decision Making." Journal of Personality and Social Psychology 68: 5-20.

Grush, R., and N. Mandelblit. 1997. "Blending in Language, Conceptual Structure, and the Cerebral Cortex." In P. A. Brandt, F. Gregersen, F. Stjernfelt, and M. Skov, eds., The Roman Jakobson Centennial Symposium: International Journal of Linguistics Acta Linguistica Hafniensia, 29: 221-237. Copenhagen: C. A. Reitzel. 


\section{References}

Hadfield, G. K. 1992. "Bias in the Evolution of Legal Rules." Georgetown Law Joumal 80: 583-616.

Hahn, F. H. 1987. "Information, Dynamics and Equilibrium." Scottish Journal of Political Economy 34: 321-334.

Hammond, J. S., R. L. Keeney, and H. Raiffa. 1998. "The Hidden Traps in Decision Making." Harvard Business Review 5: 47-58.

Hardin, R. 1971. "Collective Action as an Agreeable N-Prisoners' Dilemma." Behavioral Science 16: 472-479.

Hardin, R. 1982. Collective Action. Baltimore, MD: Johns Hopkins University Press.

Hardin, R. 1993. "The Street-Level Epistemology of Trust." Politics o Society $21: 505-529$

Harsanyi, J. 1967. "Games with Incomplete Information Played by 'Bayesian' Players, I: The Basic Model." Management Science 14: 159-182.

Harsanyi, J. 1968a. "Games with Incomplete Information Played by 'Bayesian' Players, II: Bayesian Equilibrium Points." Management Science 14: 320334.

Harsanyi, J. 1968b. "Games with Incomplete Information Played by 'Bayesian' Players, III: The Basic Probability Distribution of the Game." Management Science 14: 486-502.

Haskell, T. L. 1985. "Capitalism and the Origins of the Humanitarian Sensibilities." American Historical Review 90: 339-361, 547-566.

Hastie, R., and B. Park. 1986. "The Relationship Between Memory and Judgment Depends on Whether the Task Is Memory-Based or On-line." Psychological Review 93: 258-268.

Hastie, R., and N. Pennington. 1989. "Notes on the Distinction Between Memory-Based Versus On-line Judgments." In J. Bassili, ed., On-line Cognition in Person Perception. Hillsdale, N]: Lawrence Erlbaum, 1-18.

Hauser, M. D. 1996. The Evolution of Communication: An Introduction to Evolutionary Psychology. Cambridge, MA: Harvard University Press.

Heider, F. 1958. The Psychology of Interpersonal Relations. New York: Wiley.

Heiner R. 1983. "The Origins of Predictable Behavior." American Economic Review 73: 560-595.

Hibbs, D. 1987. The American Political Economy: Macroeconomics and Electoral Politics. Cambridge, MA: Harvard University Press.

Higgins, E. T. 1996. "Knowledge Activation: Accessibility, Applicability and Salience." In E. T. Higgins and A. Kruglanski, eds., Social Psychology: Handbook of Basic Principles. New York: Guilford Press, 133-168.

Higgs, R. 1987. Crisis and Leviathan: Critical Episodes in the Growth of American Government. New York: Oxford University Press.

Hilts, P. J. 1992. "Hole' in Tumor Patient's Memory Reveals Brain's Odd Filing System." Now York Times, Sept. 15, sec. B.

Hinich, M. J., and M. C. Munger. 1992. "Ideology and the Theory of Political Choice." Unpublished manuscript, Department of Political Science, University of North Carolina.

\section{References}

Hinich, M. J., and M. C. Munger. 1994. Ideology and the Theory of Political Choice. Ann Arbor: University of Michigan Press.

Cocial Distance and Other-

Hoffman, E., K. McCabe, and V. L. Smith. 19. American Economic Review 86: Regarding Behavior in Dictator Games." American Economic Retiew 86: 653-660.

Hoffman, E., and M. Spitzer. 1985. "Entitlements Rights and Fairness: An Experimental Examination of Subjects' Concepts of Distributive Justice." Joumal of Legal Studies 15: 254-297.

Hogarth, R. M., and M. Reder. 1987. Rational Choice: The Contrast between Economics and Psychology. Chicago: University of Chicago Press.

Holland, J. H. 1975. Adaptation in Natural and Artificial Systems: An Introductory Analysis with Applications to Biology, Control, and Artificial Intelligence. Ann Arbor: University of Michigan Press.

ligence. An 1988. "The Global Economy as an Adaptive Process." In P. W. 列 Anderson, D. Pines, and Kont Addison-Wesley, 117-124.

Complex System. Boston: Addison-Wesley, 117-124.

Holland, J. H., K. J. Holyoak, R. E. Nisbett, and P. R. Thagard. 1986. Cambridge, MA: MIT tion: Processes of Inference, Learning, and Discovery. Cambridge, MA. MIT Press.

. "Statistics and Causal Inference." Journal of the American

Holyoak, K., and P. Thagard. 1995. Mental Leaps: Analogy in Creative Thought. Cambridge, MA: MIT Press.

Houston, D. A., and S. J. Sherman. 1995 "Cancellation and Focus: The Role of Shared and Unique Features in the Choice Process." Journal of Experimental Social Psychology 31: 357-378

Houston, D. A., S. J. Sherman, and S. M. Baker. 1991. "Feature Matching, . Unique Features, and the Dynamics of the Chrnal of Experimental Social Conflict and Postdecision

Psychology 27: 411-430. Conflicting Results from Experimental

Hovland, C. I. 1959. "Reconciling Conflicting Results from Psychologist 14 and Survey Studies of Attitude Change." American Psychologist 14: 8-17.

Hovland, C. I. I. L. Janis, and H. H. Kelley. 1953. Communication and PerChange. New Haven: Yale University Press.

Huckfeldt, R., and J. Sprague. 1995. Citizens, Politics, and Social Communica tion. New York: Cambridge University Press

Hull, D. L. 1988. Science as a Process: An Evolutionary Account of the Social and Conceptual Development of Science. Chicago: University of Chicago Press.

Hurwitz, J., and M. Peffley. 1987. "How Are Foreign Policy Attitudes Struc1?" American Political Science Review 81: 1099-1120.

(the Culture Process." In C. G. Taylor, J. D. Farmer, and S. Rasmussen, eds., Artificial Life 11, Redwood Ciry, CA: Addison-Wesley, 689-706. 


\section{References}

Isaacs, H. R. 1958. Scratches on Our Minds: American Images of China and India. New York: John Day.

Isen, A. M. 1987. "Positive Affect, Cognitive Processes, and Social Behavior." In L. Berkowitz, ed., Advances in Experimental Social Psychology Vol. 21. New York: Academic Press.

Iwakura, N., and T. Saijo. 1992. "Payoff Information Effects of Public Good Provision in the Voluntary Contribution Mechanism: An Experimental Approach." Paper presented at the Annual Public Choice Meetings, March: New Orleans.

Iyengar, S. 1996. "The Case of the Vanishing Footprints: A Review of Research on Political Campaigns." Paper presented at the annual meeting of the Association for Education in Journalism, St. Petersburg, FL, September.

Iyengar, S., and D. R. Kinder. 1987. News That Matters: Television and American Opinion. Chicago: University of Chicago Press.

lyengar, S., N. Valentino, S. Ansolabehere, and A. Simon. 1996. "Running as a Woman: Gender Stereotyping in Women's Campaigns." In P. Norris, ed., Women, Media, and Politics. New York: Oxford University Press.

Jackendoff, R. 1980. Conscionsness and the Computational Mind. Cambridge, MA: MIT Press.

Jackson, M., and P. Hill. 1995. "A Fair Share." Journal of Theoretical Politics 7: 169-179.

Jacobson, G. C. 1990. "The Effects of Campaign Spending in House Elections: New Evidence for Old Arguments." American Joumal of Political Science 34: 334-362.

Jacobson, G. C. 1992. The Politics of Congressional Elections. 3d ed. New York: HarperCollins.

Jacoby, W. G. 1988. "The Impact of Party Identification on Issue Attitudes." American Journal of Political Science 32:643-661.

Jamal, K., and S. Sunder. 1988. "Money vs. Gaming: Effects of Salient Monetary Payments in Double Oral Auctions." Working Paper, No. 16-88-89, Carnegie-Mellon University.

Janis, I. L., and L. Mann. 1977. Decision Making: A Psychological Analysis of Conflict, Choice, and Commitment. New York: Free Press.

Jennings, M. K., and R. G. Niemi. 1981. Generations and Politics: A Panel Study of Young Adults and Their Parents. Princeton, NJ: Princeton University Press.

Jensen, M. C., and W. H. Meckling. 1976. "Theory of the Firm: Managerial Behavior, Agency Costs, and Ownership Structure." Joutnal of Financial Economics 3: 305-360.

Johnson, H. T., and R. S. Kaplan. 1987. Relevance Lost: The Rise and Fall of Management Accounting. Boston: Harvard Business School Press.

Johnston, R., A. Blais, E. Gidengil, and N. Nevitte. 1996. The Challenge of Direct Democracy. Montreal, Quebec: McGill-Queens University Press.

Jones, B. 1994. Reconceiving Decision-Making in Democratic Politics: Attention, Choice, and Public Policy. Chicago: University of Chicago Press.

\section{References}

Judd, C. M., and J. W. Downing. 1995. "Stereotypic Accuracy in Judgments of the Political Positions of Groups and Individuals." In M. Lodge and K. McGraw, eds., Political Judgment: Structure and Process. Ann Arbor: University of Michigan Press.

Judd, C. M., and J. Krosnick. 1989. "The Structural Basis of Consistency among Political Attitudes: Effects of Political Expertise and Attitude Importance." In A. Pratkanis, S. Becker, and A. Greenwald, eds., Attitude Structure and Function. Hillsdale, NJ: Lawrence Erlbaum Associates, 99-128.

Kahneman, D. 1995. "Varieties of Counterfactual Thinking." In N. J. Roese and J. M. Olson, eds., What Might Have Been: The Social Psychology of Counterfactual Thinking. Hillsdale, NJ: Lawrence Erlbaum.

Kahneman, D., J. L. Knetsch, and R. Thaler. 1986. "Fairness as a Constraint on Profit Seeking: Entitlements in the Market." American Economic Review 76: 728-741.

Kahneman, D., and D. Miller. 1986. "Norm Theory: Comparing Reality to Its Alternatives." Psychological Review 93: 136-153.

Kahneman, D., P. Slovic, and A. Tversky, eds. 1982. Judgment under Uncertainty: Heuristics and Biases. New York: Cambridge University Press.

Kahneman, D., and A. Tversky. 1979. "Prospect Theory: An Analysis of Decision under Risk." Econometrica 47: 263-291.

Kahneman, D., and A. Tversky. 1984. "Choices, Values, and Frames." American Psychologist 39: 341-350.

Kalai, E., and E. Lehrer. 1990. "Bayesian Learning and Nash Equilibrium." Unpublished manuscript, Department of Managerial Economics and Decision Sciences, Northwestern University.

Kandel, E. R., J. H. Schwartz, and T. M. Jessel. 1995. Essentials of Neural Science and Behavior. Norwalk, CT: Appleton \& Lange.

Kaplan, R. S. 1984. "The Evolution of Management Accounting." Accounting Review 59: 390-418.

Kaplan, R. S. 1988. "One Cost System Isn't Enough." Harvard Business Review 66: $61-66$.

Kernell, Samuel. 1993. Going Public: New Strategies of Presidential Leadership. Washington, DC: CQ Press.

Kettl, D. 1992. Deficit Politics: Public Budgeting in its Institutional and Historical Context. New York: Macmillan.

Key, V. O., Jr. 1966. The Responsible Electorate: Rationality in Presidential Voting, 1936-1960. Cambridge, MA: Harvard University Press.

Khong, Y. F. 1992. Analogies at War: Korea, Munich, Dien Bien Phu, and the Vietnam Decisions of 1965. Princeton, NJ: Princeton University Press.

Kiewiet D. R. 1983. Macroeconomics and Micropolitics. Chicago: University of Chicago Press.

Kiewiet, D. R., and M. D. McCubbins. 1991. The Logic of Delegation: Congressional Parties and the Appropriations Process. Chicago: University of Chicago Press.

Kinder, D. R. 1983. "Diversity and Complexity in American Public Opinion." 


\section{References}

In A. Finifter, ed., Political Science: The State of the Discipline. Washington, DC: American Political Science Association.

Kinder, D. R. 1986. "Presidential Character Revisited." In R. Lau and D. Sears, eds., Political Cognition. Hillsdale, NJ: Lawrence Erlbaum Associates.

Kinder, D. R., G. Adams, and P. Gronke. 1989. "Economics and Politics in the 1984 American Presidential Election." American Journal of Political Science 33: 491-515.

Kinder, D. R., and D. R. Kiewiet. 1981. "Sociotropic Politics: The American Case." British Journal of Political Science 11: 129-161.

Kinder, D. R., and D. Sears. 1985. "Public Opinion and Political Action." In G. Lindzey and E. Aronson, eds., The Handbook of Social Psychology. Vol. 1. New York: Random House.

Kite, C. M., and W. M. Rahn. 1997. "Political Community and Public Mood: A Comparison of the U.S. and Swedish Cases." Typescript, University of Umeä, Sweden.

Klayman, J., and Y. W. Ha. 1987. "Confirmation, Disconfirmation, and Information in Hypothesis Testing." Psychological Review 94: 211228.

Kleinnijenhuis, J., and J. de Ridder. 1997. "Effects of Issue Priorities in the News on Voting Preferences." In C. W. Aarts and B. Steenge, eds., Setting Priorities in the Public Sector. Dordrecht, Netherlands: Kluwer.

Knight, F. H. 1921. Risk, Uncertainty, and Profit. Boston: Houghton Mifflin Co. Reprinted 1971. Chicago: University of Chicago Press.

Konow, J. 1994. A Positive Theory of Economic Fairness. Working Paper 94081. Los Angeles: Loyola Marymount University.

Konow, J. 1995. "Which is the Fairest one of All?: Some Evidence on Theories of Fairness." Working paper (mimeo), Dept. of Economics, Loyola Marymount University, Los Angeles.

Kramer, R. M., M. B. Brewer, and B. A. Hanna. 1995. "Collective Trust and Collective Action: The Decision to Trust as a Social Decision." In R. Kramer and T. R. Tyler, eds., Trust in Organizations. Thousand Oaks, CA: Sage Publications.

Krehbiel, K. 1991. Information and Legislative Organization. Ann Arbor: University of Michigan Press.

Kreps, D. M. 1990a. A Course in Microeconomic Theory. Princeton, NJ: Princeton University Press.

Kreps, D. M. 1990b. "Corporate Culture and Economic Theory." In J. E. Alt and K. A. Shepsle, eds., Perspectives on Positive Political Economy. Cambridge: Cambridge University Press, 90-143.

Kreps, D. M., P. Milgrom, J. Roberts, and R. Wilson. 1982. "Rational Cooperation in the Finitely Repeated Prisoners' Dilemma." Journal of Economic Theory 27: 245-252.

Krosnick, J. A. 1988. "The Role of Attitude Importance in Social Evaluation: A Study of Policy Preferences, Presidential Candidate Evaluations, and Voting Behavior." Journal of Personality and Social Psychology 55: 196-210.

\section{References}

Krosnick, J. A. 1989. "Attitude Importance and Attitude Accessibility." Personality and Social Psychology Bulletin 15: 297-308.

Krosnick, J., and R. Petty. 1995. "Attitude Strength: An Overview." In R. Petty and J. Krosnick, eds., Attitude Strength: Antecedents and Consequences. Hillsdale, NJ: Lawrence Erlbaum Associates, 1-24.

Kruglanski, A. 1980. "Lay Epistemology Process and Contents." Psychological Review 87: 70-87.

Kruglanski, A., and I. Ajzen. 1983. "Bias and Error in Human Judgment." European Journal of Social Psychology 13: 1-44.

Kruglanski, A., and T. Freund. 1983. "The Freezing and Unfreezing of Lay Inferences: Effects on Impressional Primacy, Ethnic Stereotyping, and Numerical Anchoring." Journal of Experimental Social Psychology 19: 448-468.

Kruglanski, A., and D. Webster. 1996. "Motivated Closing of the Mind: 'Seizing' and 'Freezing." Journal of Personality and Social Psychology 103: 263-283.

Kuhn, T. S. 1970. The Structure of Scientific Revolutions. 2d ed. Chicago: University of Chicago Press.

Kuklinski, J. H., and N. L. Hurley. 1994. "On Hearing and Interpreting Political Messages: A Cautionary Tale of Citizen Cue-Taking." Journal of Politics 56: 729-751.

Kuklinski, J. H., and N. L. Hurley. 1996. "It's a Matter of Interpretation." In D. M. Mutz, P. M. Sniderman, and R. Brody, eds., Political Persuasion and Attitude Change. Ann Arbor: University of Michigan Press.

Kuklinski, J. H., P. J. Quirk, D. Schwieder, and R. Rich. 1997. "Misinformation and the Currency of Citizenship." Paper presented at the annual meeting of the American Political Science Association, San Francisco.

Kunda, Z. 1987. "Motivation and Inference: Self-Serving Generation and Evaluation of Evidence." Journal of Personality and Social Psychology 53: 636-647.

Kunda, Z. 1990. "The Case for Motivated Reasoning." Psychological Bulletin 1083: 480-498.

Lacroix, S. J. 1989. "Homogenous Middleman Groups: What Determines the Homogeneity?" Journal of Law, Economics, and Organization 5: 211-222.

Lakoff, G. 1987. Women, Fire and Dangerous Things. Chicago: University of Chicago Press.

Lakoff, G. 1991. "Metaphors and War." Electronic message on the Internet, January 3.

Landy, M., M. Roberts, and S. Thomas. 1990. The Environmental Protection Agency: Asking the Wrong Questions. New York: Oxford University Press.

Lane, R. 1973. "Patterns of Political Beliefs." In J. Knutson, ed., Handbook of Political Psychology. San Francisco: Jossey-Bass.

Lane, R. E. 1995. "What Rational Choice Explains." Critical Review 9: $107-126$.

Larrick, R. P. 1993. "Motivational Factors in Decision Theories: The Role of Self-Protection." Psychological Bulletin 113: 430-440. 


\section{References}

Lascher, E. L., and M. R. Powers. 1997. "Expert Opinion and Automobile Insurance Reform: An Empirical Assessment." Journal of Insurance Regulation 16(2): $197-222$.

Lau, R. 1985. "Two Explanations for Negativity Effects in Political Behavior." American Journal of Political Science 29: 119-138.

Lau, R. 1989. "Construct Accessibility and Electoral Choice." Political Behavior 20: 5-32.

Lau, R., and D. Redlawsk. 1997. "Voting Correctly." American Political Science Review 91: 585-598.

Lau, R., and D. Redlawsk. 1999. "An Experimental Study of Information Search, Memory, and Decision Making during a Political Campaign." In J. Kuklinski, ed., Citizens and Politics: Perspectives from Political Psychology. New York: Cambridge University Press.

Laver, M., and N. Schofield. 1990. Multiparty Government: The Politics of Coalition in Europe. Oxford: Oxford University Press.

Laver, M., and K. Shepsle. 1996. Making and Breaking Governments: Cabinets and Legislatures in Parliamentary Democracies. Cambridge, MA: Cambridge University Press.

Leake, D. B. 1991. "Goal-Based Explanation Evaluation." Cognitive Science 15: 509-545.

Leamer, E. E. 1987. Specification Searches: Ad Hoc Inference with Nonexperimental Data. New York: Wiley.

LeDoux, J. 1996. The Emotional Brain: The Mysterious Underpinnings of Emotional Life. New York: Simon and Schuster.

Ledyard, J. O. 1995. "Public Goods: A Survey of Experimental Research." In J. H. Kagel and A. E. Roth, eds., The Handbook of Experimental Economics. Princeton, NJ: Princeton University Press, 111-194.

Levi, M. 1996. "Social and Unsocial Capital: A Review of Putnam's Making Democracy Work." Politics é Society 24: 45-55.

Levitin, T. E., and W. E. Miller. 1979. "Ideological Interpretations of Presidential Elections." American Political Science Review 73: 751-771.

Levy F., and R. Murnane. 1992. "Earnings Levels and Earnings Inequality: A Review of Recent Trends and Proposed Explanations." Journal of Economic Literature 30: 1333-1381.

Lewin, K. 1933. "Environmental Forces." In C. Murchison, ed., A Handbook of Child Psychology. Worcester, MA: Clark University Press, 590-625.

Lewin, K. 1951. Field Theory in Social Science. New York: Harper.

Lewin, S. 1996. "Economics and Psychology: Lessons for Our Own Day from the Early Twentieth Century." Journal of Economic Literature 34: 1293-1323.

Liberman, A., and S. Chaiken. 1991. "Value Conflict and Thought-Induced Attitude Change." Joumal of Experimental Social Psychology 27: 203-216.

Lichtenstein, M., and T. Srull. 1987. "Objectives as Determinant of the Rela" tionship between Recall and Judgment." Journal of Experimental Social Psychology 23: 93-118.

Liebling, A. J. 1961. The Press. New York: Ballantine Books.

\section{References}

Lindgren, K. 1992. "Evolutionary Phenomena in a Simple Dynamics." In C. G. Langton, C. Taylor, J. D. Farmer, and S. Rasmussen, eds., Artificial Life 11 Redwood City, CA: Addison-Wesley, 295-312.

Lodge, M. 1995. "Toward a Procedural Model of Candidate Evaluation." In M. Lodge and K. M. McGraw, eds., Political Judgment: Structure and Process. Ann Arbor: University of Michigan Press.

Lodge, M., K. McGraw, and P. Stroh. 1989. "An Impression-Driven Model of Candidate Evaluation." American Political Science Review 83: 399-419.

Lodge, M., M. Steenbergen, and S. Brau. 1995. "The Responsive Voter: Campaign Information and the Dynamics of Candidate Evaluation." American Political Science Review 89: 309-326.

Lodge, M., and P. Stroh. 1993. "Inside the Mental Voting Booth: An Impression-Driven Model." In S. lyengar and W. McGuire, eds., Explorations in Political Psychology. Durham, NC: Duke University Press.

Lodge, M., and C. Taber. 2000. "Three Steps toward a Theory of Motivated Political Reasoning." In A. Lupia, M. D. McCubbins, and S. L. Popkin, eds., Elements of Reason: Understanding and Expanding the Limits of Political Rationality. New York: Cambridge University Press.

Loomes, G., and R. Sugden. 1982. "Regret Theory: An Alternative Theory of Rational Choice under Uncertainty." Economic Journal 92: 805-824.

Lord, C., M. Lepper, and E. Preston. 1984. "Considering the Opposite: a Corrective Strategy for Social Judgment." Journal of Personality and Social Psychology 47: 1231-1243.

Lord, C., M. Ross, and M. Lepper. 1979. "Biased Assimilation and Attitude Polarization: The Effects of Prior Theories on Subsequently Considered Evidence." Journal of Personality and Social Psychology 27: 20982109.

Lupia, A. 1994. "Shortcuts versus Encyclopedias: Information and Voting Behayior in California Insurance Reform Elections." American Political Science Review 88: 63-76.

Lupia, A. 2000. "Who Can Persuade Whom? How Simple Cues Affect Political Attitudes.” In J. H. Kuklinski, ed., Thinking about Political Psychology. New York: Cambridge University Press.

Lupia, A., and M. D. McCubbins. 1998. The Democratic Dilemma: Can Citizens Learn What They Need to Know? Cambridge: Cambridge University Press.

Luskin, R. C. 1987. "Measuring Political Sophistication." American Journal of Political Science 31: 856-899.

Luskin, R. C. 2000. "From Denial to Extenuation (and Finally Beyond): Political Sophistication and Citizen Performance." In J. H. Kuklinski, ed. Thinking about Political Psychology. New York: Cambridge University Press.

Mandelblit, N. 1995a. "The Theory of Blending as Part of the General Episte mological Developments in Cognitive Science." Unpublished manuscript.

Mandelblit, N. 1995b. "Beyond Lexical Semantics: Mapping and Blending of Conceptual and Linguistic Structures in Machine Translation." Proceedings 


\section{References}

of the Fourth International Conference on the Cognitive Science of Natural Language Processing, Dublin.

Mandelblit, N. 1996. "Formal and Conceptual Blending in the Hebrew Verba System: A Cognitive Basis for Morphological Verbal Pattern Alternations." Unpublished manuscript.

Mandelblit, N. 1997. Grammatical Blending: Creative and Schematic Aspects in Sentence Processing and Translation. Ph.D. dissertation, University of California, San Diego.

Mandelblit, N. In press. "Blends in Hebrew Causatives." Proceedings of the Fourth Conference of the International Cognitive Linguistics Association, Albuquerque, NM.

Mandelblit, N., and O. Zachar. 1998. "The Notion of Dynamic Unit: Conceptual Developments in Cognitive Science." Cognitive Science 22: 229-268.

Maoz, Z., and A. Shayer. 1987. "The Cognitive Structure of Peace and War Argumentation: Israeli Prime Ministers versus the Knesset." Political Psychology 8: $575-604$.

March, J. G., and J. P. Olson. 1989. Rediscovering Institutions: The Organizational Basis of Politics. New York: Free Press.

Marcus, G. E., and M. B. MacKuen. 1993. "Anxiety, Enthusiasm and the Vote: On the Emotional Underpinnings of Learning and Involvement during Presidential Campaigns." American Political Science Review 87: 672-685.

Marks, R. 1992. "Repeated Gains and Finite Automata." In J. Creedy, J. Borland, and J. Eichberger, eds., Recent Developments in Game Theory. Brookfield, VT: Edward Elgar.

Markus, H., and R. Zajonc. 1985. "The Cognitive Perspective in Social Psychology." In G. Lindzey and E. Aronson, eds., The Handbook of Social Psychology. Vol. 1. New York: Random House.

Martin, L., and M. Tesser, eds, 1992. Construction of Social Judgments. Hillsdale, NJ: Lawrence Erlbaum Associates.

Martin, L. L., D. W. Ward, J. W. Achee, and R. S. Wyer, Jr. 1993. "Mood as Input: People Have to Interpret the Motivational Implications of Their Moods." Joumal of Personality and Social Psychology 64: 317-326.

Mayer, I. D., and E. Hanson. 1995. "Mood-Congruent Judgment Over Time." Personality and Social Psychology Bulletin 21: 237-244.

Mayseless, O., and A. Kruglanski. 1987. "What Makes You So Sure? Effects of Epistemic Motivations on Judgmental Confidence." Organizational Behavior and Human Decision Processes 39: 162-183.

McCaleb, T. S., and R. E. Wagner. 1985. "The Experimental Search for Free Riders: Some Reflections and Observations." Public Choice 47: $479-490$.

McCauley, R. N., ed. 1996. The Churchlands and Their Critics. Cambridge, MA: Blackwell Publishers Inc.

McClosky, H., P. J. Hoffman, and R. O'Hara. 1960. "Issue Conflict and Consensus among Party Leaders and Followers." American Political Science Review 54: 406-427.

McDermott, M. 1997. "Voting Cues in Low-Information Elections: Candidate

\section{References}

Gender as a Social Information Variable in Contemporary U.S. Elections." American Journal of Political Science 41: 270-283.

McEachern, W. A. 1994. Macroeconomics: A Contemporary Introduction. 3d ed. Cincinnati, $\mathrm{OH}$ : College Division, South-Western Publishing Co.

McGraw, K., M. Lodge, and P. Stroh. 1990. "Candidate Evaluation: The Effect of Salience, Order, and Sophistication." Political Behavior 12: 41-58.

McGraw, K., and N. Pinney. 1990. "The Effects of General and DomainSpecific Expertise on Political Memory." Social Cognition 8: 9-30.

McGuire, W. J. 1968. "The Structure of Human Thought." In R. Abelson, E. Aronson, W. McGuire, T. Newcomb, M. Rosenberg, and P. Tannenbaum, eds., Theories of Cognitive Consistency: A Sourcebook. Chicago: Rand McNally.

McGuire, W. J. 1969. "Nature of Attitudes and Attitude Change." In G. Lindzey and E. Aronson, eds., Handbook of Social Psychology. Reading, MA Addison-Wesley.

McGuire, W. J. 1985. "Attitudes and Attitude Change." In G. Lindzey and E. Aronson, eds., Handbook of Social Psychology. New York: Random House.

McKelvey, R. D., and P. C. Ordeshook. 1986. "Information, Electoral Equilibria, and the Democratic Ideal." Journal of Politics 8: 909-937.

McKelvey, R. D., and P. C. Ordeshook. 1990. "Information and Elections: Retrospective Voting and Rational Expectations." In J. A. Ferejohn and J. H. Kuklinski, eds., Information and Democratic Processes. Urbana: University of Illinois Press.

Merelman, R. D. 1986. "Cultural Displays: An Illustration from American Immigration." Qualitative Sociology 11: 335-352.

Merrill, R. A. 1988. "FDA's Implementation of the Delaney Clause: Repudiation of Congressional Choice or Reasoned Adaptation to Scientific Progress." Yale Journal on Regulation 5: 1-88.

Miller D. T., and M. Ross. 1975. "Self-Serving Biases in the Attribution of Causality: Fact or Fiction?" Psychological Bulletin 82: 213-225.

Miller, G. J., and J. A. Oppenheimer. 1982. "Universalism in Experimental Committees." American Political Science Review 76: 561-574.

Miller, N. E. 1944. "Experimental Studies of Conflict." In J. M. Hunt, ed., Personality and the Behavior Disorders: Vol. 1. New York: Roland Press, $431-465$.

Mitchell, R. C., and R. T. Carson. 1989. Using Surveys to Value Public Goods: The Contingent Valuation Method. Baltimore, MD: Johns Hopkins University Press.

Mondak, I. 1993. "Source Cues and Policy Approval: The Cognitive Dynamics of Public Support for the Reagan Agenda." American Journal of Politica Science 37: 186-212.

Mondak, J. 1994. "Cognitive Heuristics, Heuristic Processing, and Efficiency in Political Decision-Making." In M. Delli Carpini, L. Huddy, and R. Y. Shapiro, eds., Research in Micropolitics. Vol. 4. Greenwich, CT: JAI Press.

Morris, D. 1967. The Naked Ape. New York: McGraw-Hill. 


\section{References}

Morrow, J. 1994. Game Theory for Political Scientists. Princeton, NJ: Princeton University Press.

Mroz, J. E. 1993. "Russia and Eastern Europe: Will the West Let Them Fail?" Foreign Affairs 72: 44-57.

Mutz, D. 1992. "Impersonal Influence: Effects of Representations of Public Opinion on Political Attitudes." Political Behavior 14: 89-122.

Myerson, R. B. 1983. "Mechanism Design by an Informed Principal." Econometrica 51: 1767-1797.

Myerson, R. B. 1989. "Credible Negotiation Statements and Coherent Plans." Journal of Economic Theory 48: 264-303.

Neely, J. 1977. "Semantic Priming and the Retrieval of Lexical Memory: Roles of Inhibitionless Spreading Activation and Limited-Capacity Attention." Journal of Experimental Psychology: General 106: 226-254.

Neuberg, S. 1989. "The Goal of Forming Accurate Impressions during Social Interactions: Attenuating the Impact of Negative Expectancies." Journal of Personality and Social Psychology 56:431-444.

Neuberg, S., and S. Fiske. 1987. "Motivational Influences on Impression Formation: Dependence, Accuracy-Driven Attention, and Individuating Information." Journal of Personality and Social Psychology 53: 431-444.

Neuman, W. R. 1986. The Paradox of Mass Politics: Knowledge and Opinion in the American Electorate. Cambridge, MA: Harvard University Press.

Neuman, W. R., M. Just, and A. Crigler. 1992. Common Knowledge: News and the Construction of Political Meaning. Chicago: University of Chicago Press.

Newell, A. 1990. Unified Theories of Cognition. Cambridge, MA: Harvard University Press.

Nie, N. H., S. Verba, and J. R. Petrocik. 1976. The Changing American Voter. Cambridge, MA: Harvard University Press.

Niedenthal, P. M., and M. Setterlund. 1994. "Emotional Congruence in Perception." Personality and Social Psychology Bulletin 20: 401-411.

Nisbett, R. E., and L. Ross. 1980. Human Inference: Strategies and Shortcomings of Social Judgment. Englewood Cliffs, NJ: Prentice-Hall.

Noll, R. G., and J. E. Krier. 1990. "Some Implications of Cognitive Psychology for Risk Regulation." Journal of Legal Studies 19: 747-779.

Nordhaus, W. 1975. "The Political Business Cycle." Review of Economic Studies 42: 169-190.

North, D. C. 1990 . Institutions, Institutional Change and Economic Performance. Cambridge: Cambridge University Press.

Nozick, R. 1974. Anarchy, State and Utopia. New York: Basic Books.

Oakley, T. 1995. Presence: The Conceptual Basis of Rhetorical Effect. Ph.D. dissertation, University of Maryland.

O'Flaherty, B. 1985. Rational Commitment: A Foundation for Macroeconomics. Durham, NC: Duke University Press.

Okun, A. M. 1975. Equality and Efficiency: The Big Trade-off. Washington, DC: Brookings Institution.

Olson, M. 1965. The Logic of Collective Action: Public Goods and the Theory of Groups. Cambridge, MA: Harvard University Press.

\section{References}

Olson, M. 1982. The Rise and Decline of Nations. New Haven: Yale University Press.

Olson, R. G. 1967. "Deontological Ethics." In Encyclopedia of Philosophy, 2: 343. New York: Collier Macmillan \& Free Press.

Oppenheimer, J. A. 1985. "Public Choice and Three Ethical Properties of Politics." Public Choice 45: 241-255.

Orbell, J., and R. M. Dawes. 1991. "A 'Cognitive Miser' Theory of Cooperators' Advantage." American Political Science Review 85: 515-528.

Ordeshook, P. C. 1986. Game Theory and Political Theory: An Introduction. New York: Cambridge University Press.

Ostrom, E. 1990. Governing the Commons: The Evolution of Institutions for Collective Action. Cambridge: Cambridge University Press.

Ottati, V., and R. S. Wyer, Jr. 1990. "The Cognitive Mediators of Political Choice: Toward a Comprehensive Model of Political Information Processing." In J. Ferejohn and J. Kuklinski, eds., Information and Democratic Processes. Urbana: University of Illinois Press.

Page, B. I., and R. Y. Shapiro. 1992. The Rational Public: Fifty Years of Trends in Americans ${ }^{3}$ Policy Preferences. Chicago: University of Chicago Press.

Park, B. 1989. "Trait Attributes as On-Line Organizers in Person Impressions." In J. Bassilli, ed., On-Line Cognition in Person Perception. Hillsdale, NJ: Lawrence Erlbaum Associates, 39-60.

Parkinson, B., R. B. Briner, S. Reynolds, and P. Totterdell. 1995. "Time Frames for Mood: Relationships between Momentary and Generalized Ratings of Affect." Personality and Social Psychology Bulletin 21: 331-339.

Payne, J. W. J. R. Bettman, and E. J. Johnson. 1992. "Behavioral Decision Research: A Constructive Processing Perspective." Annual Review of Psychology 43: 87-131.

Peabody, D. 1967. "Trait Inferences: Evaluative and Descriptive Aspects." Journal of Personality and Social Psychology 7: 1-18.

Pennington, N., and R. Hastie. 1986. "Evidence Evaluation in Complex Decision Making." Journal of Personality and Social Psychology 51: 242-258.

Pennington, N., and R. Hastie. 1988. "Explanation-Based Decision Making: Effects of Memory Structure on Judgment." Journal of Experimental Psychology: Learning, Memory, and Cognition 14: 521-533.

Petrocik, J. 1996. "Issue Ownership in Presidential Elections with a 1980 Case Study." American Journal of Political Science 40: 825-850.

Petty, R., and J. Cacioppo. 1984. Attitudes and Persuasion: Classic and Contemporary Approaches. Dubuque, IA: W. C. Brown.

Petty, R., and J. Cacioppo. 1986a. Communication and Persuasion: Central and Peripheral Routes to Attitude Change. New York: Springer-Verlag.

Petty, R., and J. Cacioppo. 1986b. "The Elaboration Likelihood Model of Persuasion." In L. Berkowitz, ed., Advances in Experimental Social Psychology. Vol. 19. New York: Academic Press, 123-205.

Piattelli-Palamarini, M. 1994. Inevitable Illusions: How Mistakes of Reason Rule Our Minds. New York: John Wiley. 


\section{References}

Pinker S. 1997. How the Mind Works. New York: W. W. Norton \& Company. Plotkin, H. C. 1998. Evolution in Mind: An Introduction to Evolutionary Psychology. Cambridge, MA: Harvard University Press.

Plott, C. R. 1983. "Externalities and Corrective Policies in Experimental Markets." Economic Journal 93: 106-127.

Plutchik, R. 1994. The Psychology and Biology of Emotion. New York: HarperCollins.

Polanyi, Michael. 1983. The Tacit Dimension. Gloucester, MA: Peter Smith.

Popkin, S. L. 1991. The Reasoning Voter: Communication and Persuasion in Presidential Campaigns. Chicago: University of Chicago Press.

Popkin, S. L. 1994. The Reasoning Voter: Communication and Persuasion in Presidential Campaigns. $2 \mathrm{~d}$ ed. Chicago: University of Chicago Press.

Powell, R. 1990. Nuclear Deterrence Theory: The Search for Credibility. New York: Cambridge University Press.

Pratkanis, A. 1989. "The Cognitive Representation of Attitudes." In A. Pratkanis, S. Breckler, and A. Greenwald, eds., Attitude Structure and Function. Hillsdale, NJ: Lawrence Erlbaum Associates.

Price, V., and P. Neijens. 1997. "Opinion Quality in Public Opinion Research." International Journal of Public Opinion Research 9: 336-360.

Price, V., and J. Zaller. 1993. "Who Gets the News: Alternative Measures of News Reception and Their Implications for Research." Public Opinion Ouarterly 57: 133-164.

Prior A. N. 1967. "Logic, Deontic." In Encyclopedia of Philosophy, 4: 509-512. New York: Collier Macmillan \& Free Press.

Przeworski, A. 1991. Democracy and the Market: Political and Economic Reforms in Eastern Europe and Latin America. Cambridge: Cambridge University Press.

Putnam, R. 1971. "Studying Elite Culture: The Case of Ideology." American Political Science Review 65: 651-681.

Putnam, R. 1993. Making Democracy Work. Princeton, NJ: Princeton University Press.

Putnam, R. 1995. "Bowling Alone: America's Declining Social Capital." Journal of Democracy 6: 65-78.

Pysczcynski, T., and J. Greenberg. 1987. "Toward an Integration of Cognitive and Motivational Perspectives on Social Inference: A Biased HypothesisTesting Model." In L. Berkowitz, ed., Advances in Social Psychology. Vol. 20. New York: Academic Press, 297-340.

Pysczcynski, T., J. Greenberg, and K. Holt. 1985. "Maintaining Consistency between Self-Serving Beliefs and Available Data: A Bias in Information Evaluation." Personality and Social Psychology Bulletin 11: 179190.

Quattrone, (i., and A. Tversky. 1988. "Contrasting Rational and Psychological Analyses of Political Choice." American Political Science Review 82: $719-735$.

Rae, D. 1981. Equalities. New Haven: Yale University Press.

Rahn, W., J. Aldrich, and E. Borgida. 1994. "Individual and Contextual Varia-

\section{References}

tions in Political Candidate Appraisal." American Political Science Review 88: 193-199.

Rahn, W. M., J. Brehm, and N. Carlson. 1997. "National Elections as Institutions for Creating Social Capital." Paper presented at the annual meeting of the American Political Science Association, Washington, DC.

Rahn, W. M., and R. Hirshorn. 1997. "Political Advertising and Public Mood." Unpublished manuscript, University of Minnesota.

Rahn, W. M., B. Kroeger, and C. M. Kite. 1996. "A Framework for the Study of Public Mood." Political Psychology 17: 29-58.

Rahn, W. M., and J. Transue. 1997. "The Decline of Social Trust among American Youth: The American Economy, Value Change, and Social Capital." Unpublished manuscript, University of Minnesota.

Ram, A., and D. B. Leake, eds. 1995. Goal-Driven Learning. Cambridge, MA: MIT Press.

Rauch, J. 1995. Demosclerosis: The Silent Killer of American Government. New York: Times Books.

Rawls, J. 1971. A Theory of Justice. Cambridge, MA: Harvard University Press.

Raz, J. 1986. The Morality of Freedom. New York: Clarendon Press, Oxford University Press.

Riker, W., and P. Ordeshook. 1968. "A Theory of the Calculus of Voting." American Political Science Review 62: 24-42.

Robert, A. 1996. "Blending in the Interpretation of Mathematical Proofs." Paper presented at the Second Conference on Conceptual Structure, Discourse, and Language, Buffalo, NY.

Rohde, D. 1991. Parties and Leaders in the Post-Reform House. Chicago: University of Chicago Press.

Rokeach, M. 1973. The Nature of Human Values. New York: Free Press.

Ross, L. 1977. "The Intuitive Psychologist and His Shortcomings: Distortions in the Atribution Process." In L. Berkowitz, ed., Advances in Experimental Social Psychology, 10: 174-221. New York: Academic Press.

Ross, L., and C. A. Anderson. 1982. "Shortcoming in the Attribution Process: On the Origins and Maintenance of Erroneous Assessments." In D. Kahneman, P. Slovic, and A. Tversky, eds., Judgment under Uncertainty: Heuristics and Biases. Cambridge: Cambridge University Press.

Roth, A. E. 1988. "Laboratory Experimentation in Economics: A Methodological Overview." Economic Journal 98: 974-1031.

Roth, A. E. 1995. "Bargaining Experiments." In J. H. Kagel and A. E. Roth, eds., The Handbook of Experimental Economics. Princeton, NJ: Princeton University Press, 253-342.

Rozin, P., and C. Nemeroff. 1995. "The Borders of the Self: Contamination Sensitivity and Potency of the Body Apertures and Other Body Parts." Joumal of Research in Personality 29: 318-340.

Rubenstein, A. 1998. Modeling Bounded Rationality. Cambridge, MA: MIT Press.

Rumelhart, D., and A. Ortony. 1977. "The Representation of Knowledge in 


\section{References}

Memory." In R. Anderson, R. J. Spiro, and W. E. Montague, eds., School ing and the Acquisition of Knowledge. Hillsdale, NJ: Lawrence Erlbaum.

Saijo, T., S. Takahashi, and S. Turnbull. 1996. "Justice in Income Distribution: An Experimental Approach." Presented at annual meetings of the International Studies Association, San Diego, April 18.

Saijo, T., and T. Yamaguchi. 1992. "The Spite Dilemma in Voluntary Contribu tion Mechanism Experiments." Paper presented at the annual Public Choice Meetings, New Orleans, March.

Samuelson, W., and R. Zeckhauser. 1988. "Status Quo Bias in Decision Making." Journal of Risk and Uncertainty 1: 7-59.

Sanbonmatsu, D., and R. Fazio. 1990. "The Role of Attitudes in Memory-Based Decision Making." Journal of Personality and Social Psychology 59 614-622.

Sanford, A. 1986. The Mind of Man: Models of Human Understanding. New Haven: Yale University Press.

Sanitioso, R., and Z. Kunda. 1991. "Ducking the Collection of Costly Evidence: Motivated Use of Statistical Heuristics." Journal of Behavioral Decision Making 4: 177-178.

Schank, R., and R. Abelson. 1977. Scripts, Plans, Goals, and Understanding. Hillsdale, NJ: Lawrence Erlbaum.

Schelling, T. C. 1973. "Hockey Helmets, Concealed Weapons, and Daylight Savings: A Study of Binary Choices with Externalities." Journal of Conflict Resolution 17: 381-428.

Schwarz, N., H. Bless, and G. Bohner. 1991. "Mood and Persuasion: Affective States Influence the Processing of Persuasive Communications." In M. P. Zanna, ed., Advances in Experimental Social Psychology, 24: 161-199. New York: Academic Press.

Schwarz, N., and G. Clore. 1983. "Mood, Misattribution, and Judgments of Well-Being: Informative and Directional Functions of Affective States." Journal of Personality and Social Psychology 45: 513-523.

Schwarz, N., and G. Clore. 1988. "How Do I Feel About It? The Informative Functions of Affective States." In K. Fiedler and J. Forgas, eds., Affect, Cognition, and Social Behavior. Toronto: Hogrefe International, 44-62.

Sears, D. O. 1983. "The Persistence of Early Political Predispositions: The Roles of Attitude Object and Life Stage." In L. Wheeler and W. J. McGuire, eds, Political Socialization, Citizenship Education, and Democracy. New York: Teachers College Press.

Sears, D. O., L. Huddy, and L. Schaffer. 1986. "A Schematic Variant of Symbolic Politics Theory, as Applied to Racial and Gender Equality." In R. Lau and D. Sears, eds., Political Cognition. Hillsdale, NJ: Lawrence Erlbaum Associates, 159-202.

Seligman, A. B. 1997. The Problem of Trust. Princeton, NJ: Princeton University Press.

Shaw, D. 1997. "Candidate Appearances and Television Advertising in the 1988-1996 Presidential Elections." Paper presented at the annual meeting of the American Political Science Association, Washington, DC, September.

\section{References}

Shepsle, K. 1978. The Giant Jigsaw Puzzle: Democratic Committee Assignments in the Modern House. Chicago: University of Chicago Press.

Shepsle, K. 1979. "Institutional Arrangements and Equilibrium in Multidimensional Voting Models." American Journal of Political Science 23: 27-60.

Shepsle, K., and B. R. Weingast. 1981. "Structure Induced Equilibrium and Legislative Choice." Public Choice 37: 503-519.

Shepsle, K., and B. R. Weingast, eds. 1995. Positive Theories of Congressional Institutions. Ann Arbor: University of Michigan Press.

Simon, A. 1997. The Winning Message. Ph.D. dissertation, University of California, Los Angeles.

Simon, H. A. 1957. Models of Man. New York: John Wiley.

Simon, H. A. 1959. "Theories of Decision Making in Economics and Behavioral Science." American Economic Review: 253-283.

Simon, H. A. 1967. "Motivational and Emotional Controls of Cognition." Psy. chological Review 74: 29-39.

Simon, H. A. 1978. "Rationality as Process and Product of Thought." American Economic Review: Proceedings 68: 1-16. Reprinted in Simon 1982.

Simon, H. A. 1982. Models of Bounded Rationality. 2 vols. Cambridge, MA: MIT Press.

Simon, H. A. 1985. "Human Nature in Politics: The Dialogue of Psychology with Political Science." American Political Science Review 79: 293-304.

Simon, H. A. 1986. "Rationality in Economics and Psychology." Journal of Business 59; reprinted in Hogarth and Reder 1987, 25-40.

Simon, H. A. 1995. "Rationality in Political Behavior." Political Psychology 16: 45-61.

Slovic, P., D. Griffin, and A. Tversky, 1990. "Compatibility Effects in Judgment and Choice." In R. M. Hogarth, ed., Insights in Decision-Making: Theory and Applications. Chicago: University of Chicago Press.

Smith, A. 1991. National Identity. Reno: University of Nevada Press.

Smith, E. R. 1993. "Social Identity and Social Emotion: Toward a New Conceptualization of Prejudice." In D. M. Mackie and D. L. Hamilton, eds., Affect, Cognition, and Stereotyping: Interactive Processes in Group Perception. New York: Academic Press.

Smith, E. R., and S. Henry. 1996. "The In-Group Becomes Part of the Self: Response Time Evidence." Personality and Social Psychology Bulletin 22: 635-642.

Smith, V. L. 1991. "Rational Choice: The Contrast between Economics and Psychology." Journal of Political Economy 99:877-897.

Smith, V. L., and J. M. Walker. 1990. "Monetary Rewards and Decision Cost in Experimental Economics." Unpublished manuscript, Economic Science Laboratory, University of Arizona.

Sniderman, P. M. 1993. "The New Look in Public Opinion Research." In A. Finifter, ed., Political Science: The State of the Discipline II. Washington, DC: American Political Science Association.

Sniderman, P. M., R. A. Brody, and P. E. Tetlock. 1991. Reasoning and Choice: 


\section{References}

Explorations in Political Psychology. New York: Cambridge University Press.

Sniderman, P. M., J. F. Fletcher, P. H. Russell, and P. E. Tetlock. 1996. The Clash of Rights: Liberty, Equality, and Legitimacy in Pluralist Democracy. New Haven: Yale University Press.

Sniderman, P. M., J. M. Glaser, and R. Griffin. 1990. "Information and Electoral Choice." In J. Ferejohn and J. Kuklinski, eds., Information and Democratic Processes. Urbana: University of Illinois Press.

Sniderman, P. M., P. Peri, R. DeFiguredo, and T. Piazza. 2000. The Outsider: Prejudice and Politics in Modern Italy. Princeton, NJ: Princeton University Press.

Snyder, J. 1991. Myths of Empires: Domestic Politics and International Ambition. Ithaca, NY: Cornell University Press.

Snyder, J. 1996. "Military Force and Regional Order." In E. A. Kolodziej and R. Kanet, eds., Coping With Conflict After the Cold War. Baltimore, MD: Johns Hopkins University Press.

Sowell, T. 1980. Knowledge and Decisions. New York: Basic Books.

Spellman, B. A., and K. Holyoak. 1992. "If Saddam is Hitler Then Who is George Bush? Analogical Mapping Between Systems of Social Roles." Journal of Personality and Social Psychology 6: 913-933.

Spence, M. 1973. "Job Market Signaling." Quarterly Joumal of Economics 87: $355-374$.

Spillman, L. 1997. Nation and Commemoration: Creating National Identities in the United States and Australia. New York: Cambridge University Press.

Stein, Herbert. 1984. Presidential Economics: The Making of Economic Policy from Roosevelt to Reagan and Beyond. New York: Simon and Schuster.

Steinbruner, J. D. 1974. The Cybernetic Theory of Decision. Princeton, NJ: Princeton University Press.

Stevens, L., and S. Fiske. 1995. "Motivation and Cognition in Social Life: A Social Survival Guide." Social Cognition 13: 189-214.

Stimson, J. A. 1991. Public Opinion in America: Moods, Cycles, and Stwings. Boulder, CO: Westview.

Stimson, J. A., M. B. Mackuen, and R. S. Erikson. 1995. "Dynamic Representation." American Political Science Review 89: 543-565.

Stonier, A. W., and D. C. Hague. 1973. A Textbook of Economic Theory, 4th ed. New York: John Wiley \& Sons.

Suedfeld, P. 1985. "Cognitive Managers and Their Critics." Political Psychology 13: 435-454.

Suedfeld, P., S. Bluck, L. Loewen, and D. Elkins. 1994. "Sociopolitical Values and Integrative Complexity of Members of Student Political Groups." Canadian Journal of Political Science 26: 121-141.

Suedfeld, P., and A. B. C. Walbaum. 1992. "Altering Integrative Complexity in Political Thought: Value Conflict and Audience Agreement." InterAmerican Journal of Psychology 26: 19-36.

\section{References}

Sunstein, C. R. 1990. "Paradoxes of the Regulatory State." University of Chicago Law Review 57: 407-441.

Sunstein, C. R. 1993. "Endogenous Preferences, Environmental Law." Joumal of Legal Studies 22: 217-254.

Sweeney, P., and K. Gruber. 1984. "Selective Exposure: Voter Information Preferences and the Watergate Affair." Journal of Personality and Social Psychology 46: 1208-1221.

Taber, C. S. In press. "The Interpretation of Foreign Policy Events: A Cognitive Process Theory." In D. A. Sylvan, and J. F. Voss, eds., Problem Representation in Political Decision Making. London: Cambridge University Press.

Taber, C. S., M. Lodge, and J. Glather. 2000. "The Motivated Construction of Political Judgements." In J. H. Kuklinski, ed., Thinking About Political Psychology. New York: Cambridge University Press.

Taber, C. S., and M. Steenbergen. 1995. "Computational Experiments in Candidate Evaluation." In M. Lodge and K. McGraw, eds., Political Judgment: Structure and Process. Ann Arbor: University of Michigan.

Taber, C. S., and R. Timpone. 1996. Computational Modeling. Sage University Paper Series on Quantitative Applications in the Social Sciences, 07-113. Newbury Park, CA: Sage.

Tesser, A. 1986. "Some Effects of Self-evaluation Maintenance on Cognition and Action." In R. Sorrentino and E. T. Higgins, eds., The Handbook of Motivation and Cognition: Foundations of Social Behavior. New York: Guilford Press, $435-464$.

Tetlock, P. E. 1981a. "Pre- to Post-Election Shifts in Presidential Rhetoric: Impression Management or Cognitive Adjustment?" Journal of Personality and Social Psychology 41: 207-212.

Tetlock, P. E. 1981b. "Personality and Isolationism: Content Analysis of Senatorial Speeches." Joumal of Personality and Social Psychology 41: $737-743$.

Tetlock, P. E. 1983. "Cognitive Style and Political Ideology." Journal of Personality and Social Psychology 45: 118-126.

Tetlock, P. E. 1984. "Cognitive Style and Political Belief Systems in the British House of Commons." Journal of Personality and Social Psychology 46: $365-375$.

Tetlock, P. E. 1985. "Accountability: A Social Check on the Fundamental Attribution Error." Social Psychology Quarterly 48: 227-238.

Tetlock, P. E. 1986. "A Value Pluralism Model of Ideological Reasoning." Joumal of Personality and Social Psychology 50: 819-827.

Tetlock, P. E. 1989. "Structure and Function in Political Belief Systems." In A. R. Pratkanis, S. J. Breckler, and A. G. Greenwald, eds., Attitude Structure and Function. Hillsdale, NJ: Lawrence Erlbaum, 129-151.

Tetlock, P. E. 1991. "An Alternative Model of Judgment and Choice: People as Politicians." Theory and Psychology 1: 451-477.

Tetlock, P. E. 1992. "The Impact of Accountability on Judgment and Choice: Toward a Social Contingency Model." In M. Zanna, ed., Advances in 


\section{References}

Experimental Social Psychology, 25: 331-376. San Diego, CA: Academic Press.

Tetlock, P. E., D. Armor, and R. S. Peterson. 1994. "The Slavery Debate in Antebellum America: Cognitive Style, Value Conflict, and the Limits of Compromise." Joumal of Personality and Social Psychology 66: 115-126.

Tetlock, P. E., and A. Belkin, eds. 1996. Connterfactual Thought Experiments in World Politics. Princeton, NJ: Princeton University Press.

Tetlock, P. E., and R. Boettger. 1994. "Accountability Amplifies the Status Quo Effect When Change Creates Victims." Journal of Bebavioral Decision Making 7: 1-23.

Tetlock, P. E., and J. I. Kim. 1987. "Accountability and Judgment Processes in a Personality Prediction Task." Journal of Personality and Social Psychol ogy 52: 700-709.

Tetlock, P. E., P. Micheletti, and K. Hannum. 1984. "Stability and Change in Senatorial Debate: Testing the Cognitive versus Rhetorical Style Hypothesis." Journal of Personality and Social Psychology 46: 979-990.

Tetlock, P. E., R. Peterson, and J. Berry. 1993. "Flattering and Unflattering Personality Portraits of Integratively Simple and Complex Managers." Journal of Personality and Social Psychology 64: 500-511.

Tetlock, P. E., R. Peterson, and J. Lerner. 1996. "Revising the Value Pluralism Model: Incorporating Social Content and Context Postulates." In C. Seligman, J. Olson, and M. Zanna, eds., Ontario Symposium on Social and Personality Psycbology: Values. Hillsdale, NJ: Lawrence Erlbaum.

Tetlock, P. E., L. Skitka, and R. Boettger. 1989. "Social and Cognitive Strategies of Coping with Accountability: Conformity, Complexity, and Bolstering." Journal of Personality and Social Psychology 57: 632-641.

Tetlock, P. E., and A. Tyler. In press. "Winston Churchill's Cognitive Style: The Debate over Appeasement of Nazi Germany and Self-Governance for India." Political Psychology 17: 149-170.

Thaler, R. 1991. Quasi Rational Economics. New York: Russell Sage Foundation.

Tufte, E. 1978. Political Control of the Economy. Princeton, NJ: Princeton University Press.

Turner, M. 1987. Death is the Mother of Beauty: Mind, Metaphor, Criticism. Chicago: University of Chicago Press.

Turner, M. 1989. "Categories and Analogies." In D. Helman, ed., Analogical Reasoning: Perspectives of Artificial Intelligence, Cognitive Science, and Philosophy. Dordrecht Netherlands: Kluwer, 3-24.

Turner, M. 1991. Reading Minds: The Study of English in the Age of Cognitive Science. Princeton, NJ: Princeton University Press.

Turner, M. 1996a. "Conceptual Blending and Counterfactual Argument in the Social and Behavioral Sciences." In P. Tetlock and A. Belkin, eds., Counterfactual Thought Experiments in World Politics. Princeton, NJ: Princeton University Press, 291-295.

Tumer, M. 1996b. The Literary Mind: The Origins of Thought and Language. New York: Oxford University Press.

\section{References}

Turner M, and G. Fauconnier. 1995. "Conceptual Integration and Formal Expression." Metaphor and Symbolic Activity 10: 183-203.

Turner, M., and G. Fauconnier. 1998. "Conceptual Integration in Counterfactuals." In J. P. Koenig, ed., Conceptual Structure, Discourse, and Language, II. Stanford, CA: Center for the Study of Language and Information.

Turner, M., and G. Fauconnier. 1999. "A Mechanism of Creativity." Poetics Today 20: 397-418.

Tversky, A. 1972. "Elimination by Aspects: A Theory of Choice." Psychological Review 79: 281-299.

Tversky, A. 1977. "Features of Similarity." Psychological Review 84: 327-352.

Tyersky, A., and D. Kahneman. 1974. "Judgment Under Uncertainty: Heuristics and Biases." Science 185: 1124-1131.

Tversky, A., and D. Kahneman. 1981. "The Framing of Decisions and the Psychology of Choice." Science 211: 453-458.

Tversky, A., and D. Kahneman. 1986. "Rational Choice and the Framing of Decisions." Journal of Business 59: 251-278; reprinted in Hogarth and Reder 1987, 67-94.

Tversky, A., S. Sattath, and P. Slovic. 1988. "Contingent Weighting in Judgment and Choice." Psychological Review 95: 371-384.

Tversky, A., and R. H. Thaler. 1990. "Preference Reversals." Journal of Economic Perspectives 4: 201-211.

Uleman, J., and J. Bargh. 1989. Unintended Thought. New York: Guilford Press.

Uslaner, E. M. 1996. "Faith, Hope, and Charity: Social Capital, Trust, and Collective Action." Unpublished manuscript, University of Maryland.

Valavanis, S. 1958. "The Resolution of Conflict When Utilities Interact." Journal of Conflict Resolution 2: 156-169.

Vallone, R., L. Ross, and M. Lepper. 1985. "The Hostile Media Phenomenon: Biased Perception and Perceptions of Media Bias in Coverage of the Beirut Massacre." Joumal of Personality and Social Psychology 49: 577585.

Veale, T. 1996. "Pastiche: A Metaphor-Centred Computational Model of Conceptual Blending, with Special Reference to Cinematic Borrowing." Manuscript available from http://www.wam.umd.edu/ mturn/WWW/blending. html.

Viscusi, W. K. 1992. Fatal Trade-offs: Public and Private Responsibilities for Risk. New York: Oxford University Press.

Von Neumann, J., and O. Morganstern. 1944. Theory of Games and Economic Behavior. Princeton, NJ: Princeton University Press.

Walsh, V. 1996. Rationality, Allocation, and Reproduction. Oxford: Clarendon Press.

Walzer, M. 1983. Spheres of Justice. New York: Basic Books.

Wason, P. 1966. "Reasoning." In B. M. Foss, ed., New Horizons in Psychology. London: Penguin.

Wegener, D. T., and R. E. Petty. 1995. "Flexible Correction Processes in Social 


\section{References}

Judgment: The Role of Naive Theories in Corrections for Perceived Bias." Journal of Personality and Social Psychology 68: 36-51.

Wilcox, C., L. Sigelman, and E. Cook. 1989. "Some Like It Hot: Individual Differences in Response to Group Feeling Thermometers." Public Opinion Quarterly 53: 246-257.

Wildavsky, A. 1988. Searching for Safety. New Brunswick, NJ: Transaction Publishers.

Wildavsky, A., and K. Dake. 1990. "Theories of Risk Perception: Who Fears What and Why?" Daedalus: Joumal of the American Academy of Arts and Sciences 119: 41-60.

Williamson, O. E. 1975. Markets and Hierarchies, Analysis and Antitrust Impli cations: A Study in the Economics of Internal Organization. New York: Free Press.

Wilson, T, and S. Hodges. 1992. "Attitudes as Temporary Constructs." In L. Martin and A. Tesser, eds., Construction of Social Judgments. Hillsdale, NJ: Lawrence Erlbaum, 37-65.

Wittman, D. 1995. The Myth of Democratic Failute: Why Political Institutions Are Efficient. Chicago: University of Chicago Press.

Woolley, J. T. 1998. "Exorcising Inflation-Mindedness: The Transformation of Economic Management in the 1970s." Joumal of Policy History 10: $130-152$.

Wrong, D. H. 1994. The Problem of Order: What Unites and Divides Society. Cambridge, MA: Harvard University Press.

Wyer, R., and T. Srull. 1989. Memory and Cognition in Its Social Context. Hillsdale, NJ: Lawrence Erlbaum Associates.

Zajonc, R. 1980. "Preferences Need No Inferences." American Psychologist 35. 151-175.

Zajonc, R. 1984. "On the Primacy of Affect." American Psychologist 39. $117-123$.

Zaller, J. R. 1992. The Nature and Origins of Mass Opinion. New York: Cambridge University Press.

Zaller, J. R. 1998. "Monica Lewinsky's Contribution to Political Science." P.S.: Political Science and Politics 31: 182-189.

Zaller, J. R., and S. Feldman. 1992. "A Simple Theory of the Survey Response." American Journal of Political Science 36: 579-616.

Zanna, M. 1990. "Attitude Function: Is it Related to Attitude Structure?" Advances in Consumer Research 17: 98-100.

Zbikowski, L, 1997. "Conceptual Blending and Song." Unpublished manuscript, University of Chicago.

Zeckhauser, R. J., and W. K. Viscusi. 1995. "Risk within Reason." In J. Simon, ed., The State of Humanity. Oxford: Basil Blackwell, 628-637.

\section{Author Index}

Abelson, R., 182, 185, 193

Achee, J. W., $130 \mathrm{n}$

Adams, G., 220n

Aldrich, J. H., 3n, 228

Allwood, C. M., 172, 178

Althaus, S. L , 157,160

Anderson, J. $132 n, 195$

Anderson, $J_{1,1} 132 \mathrm{n}, 195$

Anderson, $\mathrm{N}$, ,

Ansolabehere, S., 110, 121t, 129, 168, 178

Aristotle, 56

Armor, D., 248

Arrow, K. J., 45, 89n

Arthur, W. B., 30, 31, 32n, 34, 40, 46

Aumann, R. ]., 23n

Axelrod, R., 87n

Bacon, F., 183

Bargh, J., 183, 190, 195, 198, 200, 201n

Barkow, J. H., 162n, 164, 16.

Baron, D. P., $57 \mathrm{n}$

Barsalou, L., 193

Bartels, L. M., 136, 217

Basinger, $S$., xi

Bates, R. H, 3n

Batson, C. D., 86n, 133n

Baumer, D. L., 110

Baumol, W. J., 103

Bechara, A., 134, 135

Becker, C. L., 44

Becker, G., 239, 246

Bell, D., 244

Bennett, W. L., 132n, 214

Berelson, B. R., 3, 190

Berent, M. K., 136

Berlin, I., 240, 245, 247

Berry, J., 261

Bettelheim, B., 216

Bikhchandani, 5, 42 n

Binmore, K., 23n, 103
Blais, A., $72 \mathrm{n}$

Bless, H., 130n, 131

Bobbitt, P., 256

Bodenhausen, G. V., $131 n$

Boettger, R., 245

Bogdan, R. I., 162n

Bohner, G., $130 \mathrm{n}$

Bond, P., 84, 90, 93n, 106

Boniger, D. S., 136

Borgida, E., 228

Boschman, I., 84, 90, 93n, 10

Boynton, G. R., 186, 195

Brady, H. E., 71, 72, 155, 159, 215

Brau, S., 183, 186

Brehm, J., 132n, 141, 218

Brewer, M. B., 141

Brewer, P. R., 218

Briner, R. B, 135n

Brody, R. A., 47, 54n, 67n, 69, 130, 131 $133 \mathrm{n}, 153,157 \mathrm{n}, 189$

Bryant, A., 269

Buchanan, B., 109

Budge, I., 110

Bueno de Mesquita, B., 3n

Cacioppo, J. T., 109, 166, 169, 185, 188

Cain, B. E., 3n

Cain, M., 97n, 106

Calabresi, G., 256

Calvert, R., $33 \mathrm{n}$

Campagna, A. S., 180

Campbell, Angus, 71, 136n, 155, 190, 216,230

Campbell, Andrea, xi

Campbell, D. T., 40n

Carlson, N., $132 \mathrm{n}$

Carmines, E. G., 82, 153n, 155, 156

Chaiken, S., 185, 195, 198, 200, 201n, 287

Cherniak, C., $4.5 \mathrm{n}$ 